\title{
Water-saving ground cover rice production system reduces net greenhouse gas fluxes in an annual rice-based cropping system
}

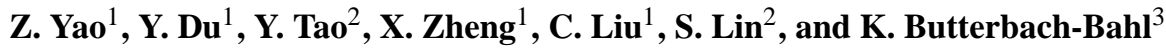 \\ ${ }^{1}$ State Key Laboratory of Atmospheric Boundary Layer Physics and Atmospheric Chemistry, \\ Institute of Atmospheric Physics, Chinese Academy of Sciences, Beijing 100029, China \\ ${ }^{2}$ College of Resource and Environmental Science, China Agricultural University, Beijing 100193, China \\ ${ }^{3}$ Institute for Meteorology and Climate Research, Atmospheric Environmental Research, Karlsruhe \\ Institute of Technology, 82467 Garmisch-Partenkirchen, Germany \\ Correspondence to: C. Liu (lcy@post.iap.ac.cn)
}

Received: 1 April 2014 - Published in Biogeosciences Discuss.: 13 June 2014

Revised: 3 October 2014 - Accepted: 9 October 2014 - Published: 17 November 2014

\begin{abstract}
To safeguard food security and preserve precious water resources, the technology of water-saving ground cover rice production system (GCRPS) is being increasingly adopted for rice cultivation. However, changes in soil water status and temperature under GCRPS may affect soil biogeochemical processes that control the biosphere-atmosphere exchanges of methane $\left(\mathrm{CH}_{4}\right)$, nitrous oxide $\left(\mathrm{N}_{2} \mathrm{O}\right)$ and carbon dioxide $\left(\mathrm{CO}_{2}\right)$. The overall goal of this study is to better understand how net ecosystem greenhouse gas exchanges (NEGE) and grain yields are affected by GCRPS in an annual rice-based cropping system. Our evaluation was based on measurements of the $\mathrm{CH}_{4}$ and $\mathrm{N}_{2} \mathrm{O}$ fluxes and soil heterotrophic respiration $\left(\mathrm{CO}_{2}\right.$ emissions) over a complete year, and the estimated soil carbon sequestration intensity for six different fertilizer treatments for conventional paddy and GCRPS. The fertilizer treatments included urea application and no $\mathrm{N}$ fertilization for both conventional paddy (CUN and CNN) and GCRPS (GUN and GNN), and solely chicken manure (GCM) and combined urea and chicken manure applications (GUM) for GCRPS. Averaging across all the fertilizer treatments, GCRPS increased annual $\mathrm{N}_{2} \mathrm{O}$ emission and grain yield by 40 and $9 \%$, respectively, and decreased annual $\mathrm{CH}_{4}$ emission by $69 \%$, while GCRPS did not affect soil $\mathrm{CO}_{2}$ emissions relative to the conventional paddy. The annual direct emission factors of $\mathrm{N}_{2} \mathrm{O}$ were 4.01, 0.09 and $0.50 \%$ for GUN, GCM and GUM, respectively, and $1.52 \%$ for the conventional paddy (CUN). The annual soil carbon sequestration intensity under GCRPS was estimated to be an average of $-1.33 \mathrm{Mg} \mathrm{Cha}^{-1} \mathrm{yr}^{-1}$, which is approxi-
\end{abstract}

mately $44 \%$ higher than the conventional paddy. The annual NEGE were $10.80-11.02 \mathrm{Mg} \mathrm{CO}_{2}$-eq ha ${ }^{-1} \mathrm{yr}^{-1}$ for the conventional paddy and 3.05-9.37 $\mathrm{Mg} \mathrm{CO}_{2}$-eq ha ${ }^{-1} \mathrm{yr}^{-1}$ for the GCRPS, suggesting the potential feasibility of GCRPS in reducing net greenhouse effects from rice cultivation. Using organic fertilizers for GCRPS considerably reduced annual emissions of $\mathrm{CH}_{4}$ and $\mathrm{N}_{2} \mathrm{O}$ and increased soil carbon sequestration, resulting in the lowest NEGE $\left(3.05-5.00 \mathrm{Mg} \mathrm{CO}_{2}-\right.$ eq $\mathrm{ha}^{-1} \mathrm{yr}^{-1}$ ). Accordingly, water-saving GCRPS with organic fertilizer amendments was considered the most promising management regime for simultaneously achieving relatively high grain yield and reduced net greenhouse gas emission.

\section{Introduction}

Atmospheric methane $\left(\mathrm{CH}_{4}\right)$, nitrous oxide $\left(\mathrm{N}_{2} \mathrm{O}\right)$ and carbon dioxide $\left(\mathrm{CO}_{2}\right)$ are key compounds in biogeochemical carbon and nitrogen cycling, thereby playing important roles for atmospheric chemistry and climate change (IPCC, 2007). Agriculture, without considering land use change, has been estimated to contribute approximately $10-12 \%$ of the total global anthropogenic emissions of greenhouse gases (GHGs), which accounts for about 50 and $60 \%$ of global $\mathrm{CH}_{4}$ and $\mathrm{N}_{2} \mathrm{O}$ emissions, respectively (Smith et al., 2007). In agricultural soils, these GHGs are all produced or consumed as a result of soil microbial processes, but the magnitude of the fluxes depends heavily on agricultural systems (Linquist 
et al., 2012). Aerobic upland agricultural systems primarily release $\mathrm{N}_{2} \mathrm{O}$ and contribute little to the global atmospheric $\mathrm{CH}_{4}$ budget (e.g., Adviento-Borbe et al., 2007; Wang et al., 2011), while paddy field and irrigated lowland rice cultivation systems are known to be significant sources of atmospheric $\mathrm{CH}_{4}$, and also $\mathrm{N}_{2} \mathrm{O}$ (e.g., Cai et al., 1997; Shang et al., 2011; Yao et al., 2012). Across 62 study sites and 328 observations worldwide, Linquist et al. (2012) estimated that the aggregate emission of $\mathrm{CH}_{4}$ and $\mathrm{N}_{2} \mathrm{O}$ in rice production systems was approximately 4 times higher than that of either upland wheat or maize systems, suggesting greater mitigation opportunities for rice systems. Therefore, measurements of GHG fluxes from different rice-based cropping systems are of regional and global significance.

Rice is the major staple food of more than 3 billion people worldwide, accounting for approximately $20 \%$ of their overall energy intake (FAO, 2011). To meet the food demand of a growing population, an annual increase in rice production in the range of $8-10$ million tons is needed over the next 20 years (Liu et al., 2013). Meanwhile, because of intensified competition for freshwater resources between agricultural and industrial development and as a result of rapid urbanization, it is anticipated that by 2025 approximately 15-20 million hectares of irrigated rice will suffer from water scarcity (Bouman, 2007). Overall, food security in the world is challenged by increasing food demand and threatened by declining water availability, and thus, a number of studies on water-saving irrigation management for rice production systems have been carried out (e.g., Bouman and Tuong, 2001; Belder et al., 2004; Qu et al., 2012; Hou et al., 2012). However, the majority of these experiments were only focused on water use efficiency and rice productivity, and little is known about the influences of management practices on GHG emissions from rice-based cropping systems. Accordingly, it is still unresolved if increased rice yields can be obtained at lower environmental costs, i.e., decreased irrigation water demand and at the same time decreased GHG emissions (Bouman et al., 2006).

China is the world's largest rice producer, contributing approximately $35 \%$ of the total global rice production $(\mathrm{Qu}$ et al., 2012). Moreover, with regard the amount of irrigation water, China is the second biggest consumer in the world, with water use in the agricultural sector accounting for $62 \%$ of total freshwater use (Wang et al., 2012). Furthermore, agriculture in China is thought to be a major source of national GHG emissions, which is responsible for approximately $17-20 \%$ of annual anthropogenic GHG emissions (Wang et al., 2012). It is generally recognized that water management is one of the most important practices that impact $\mathrm{CH}_{4}$ and $\mathrm{N}_{2} \mathrm{O}$ emissions as well as grain yields in rice paddy fields (e.g., Minamikawa and Sakai, 2005; Kreye et al., 2007; Qin et al., 2010; Yang et al., 2012). Keeping rice paddies continuous waterlogged requires the consumption of large amounts of water (approximately $3000-5000 \mathrm{~L} \mathrm{~kg}^{-1}$ of grain, Bouman et al., 2002), and results in huge $\mathrm{CH}_{4}$ emis- sions (approximately $24 \mathrm{~g} \mathrm{CH}_{4} \mathrm{~kg}^{-1}$ of grain, Linquist et al., 2012). In contrast, the management of mid-season drainage, which causes anaerobic and aerobic alternation in paddy fields, is considered to be an effective option for reducing $\mathrm{CH}_{4}$ emissions and exerting a positive impact on rice yields (e.g., Cai et al., 1997; Yan et al., 2003; Zou et al., 2005a). Meanwhile, intermittent irrigation with mid-season drainage is the standard procedure of Chinese farmers, and the introduction of this technology at the end of the last century onwards has helped to significantly reduce $\mathrm{CH}_{4}$ emissions from paddy fields (e.g., Yan et al., 2009). However, irrigation water demand for paddy rice cultivation still remains high, and it is estimated that at current levels of water usage in China, the annual total water shortage is approximately $30-40$ billion $\mathrm{m}^{3}$, and by 2050 the total water deficit could reach 400 billion $\mathrm{m}^{3}$, representing about $80 \%$ of the current annual capacity (Liu et al., 2013).

Considering the decreasing water availability for agriculture and the increasing demand for rice production, water-saving management practices have become part of the China's most important policies (Hou et al., 2012), and various water-saving technologies have been proposed and practiced in the paddy fields (e.g., Xu et al., 2004; Kreye et al., 2007, Yang et al., 2012). One of the most promising technologies to overcome water scarcity and temperature limitations in rice cultivation, the latter being specifically a problem in mountainous and rice-producing regions in the north of China, is named the ground cover rice production system (GCRPS). For the GCRPS practice, the soil surface is covered with a thin plastic film to reduce evaporation and increase soil temperature. The technology allows growing traditional lowland rice cultivars at nearly saturated soil conditions with no standing water. This practice has been proven to reduce irrigation water demand by $40-60 \%$ and increasing rice yields at long-term experimental sites by on average $10 \%$ (Qu et al., 2012) and at the regional scale by approximately $18 \%$ (Liu et al., 2013).

GCRPS technology was first tested approximately 2 decades ago; it is now widely disseminated and practiced in more than 4 million hectares in several provinces of China such as Hubei, Sichuan, Ningxia and Heilongjiang. However, changing soil conditions from permanently flooded to saturated, and covering the soil with a thin plastic film has consequences for soil temperature and redox potential $\left(E_{\mathrm{h}}\right)$. Both environmental factors are expected to lead to changes in soil biogeochemical cycling of $\mathrm{C}$ and N. For example, the increase in soil $E_{\mathrm{h}}$ under GCRPS (Liu et al., 2013) is anticipated to reduce $\mathrm{CH}_{4}$ emissions. However, the practice that enhances soil temperature and aeration status may result in increased $\mathrm{N}_{2} \mathrm{O}$ emissions (Wang et al., 2011) and mineralization rates of soil organic carbon (Qu et al., 2012), which may offset or overshadow the positive effects which can be achieved with regard to reductions in $\mathrm{CH}_{4}$ emissions. Consequently, a comprehensive assessment of the impact of GCRPS on GHG fluxes needs to take into account $\mathrm{CH}_{4}$ 
Table 1. Field management practices for different fertilizer treatments in the conventional paddy and ground cover rice production systems over the rice-growing season of 2011.

\begin{tabular}{|c|c|c|c|c|c|}
\hline \multirow[b]{2}{*}{ Treatment $^{\mathrm{a}}$} & \multicolumn{3}{|c|}{$\mathrm{N}$ application rate $\left(\mathrm{kg} \mathrm{Nha}^{-1}\right)$} & \multirow[b]{2}{*}{ Water management ${ }^{\mathrm{b}}$} & \multirow[b]{2}{*}{$\begin{array}{l}\text { Transplanting } \\
\text { and harvest date }\end{array}$} \\
\hline & Urea & $\begin{array}{l}\text { Chicken } \\
\text { manure }\end{array}$ & Total & & \\
\hline \multicolumn{6}{|c|}{ Conventional paddy } \\
\hline $\mathrm{CNN}$ & 0 & 0 & 0 & F-D-F & 29 Apr and 22 Sep 2011 \\
\hline CUN & 150 & 0 & 150 & F-D-F & 29 Apr and 22 Sep 2011 \\
\hline \multicolumn{6}{|c|}{ Ground cover rice production system (GCRPS) } \\
\hline GNN & 0 & 0 & 0 & Moist but no standing water & 29 Apr and 22 Sep 2011 \\
\hline GUN & 150 & 0 & 150 & Moist but no standing water & 29 Apr and 22 Sep 2011 \\
\hline GCM & 0 & 150 & 150 & Moist but no standing water & 29 Apr and 22 Sep 2011 \\
\hline GUM & 75 & 75 & 150 & Moist but no standing water & 29 Apr and 22 Sep 2011 \\
\hline
\end{tabular}

and $\mathrm{N}_{2} \mathrm{O}$ emissions simultaneously and, in some cases, soil carbon sequestration changes. Failure to include one or more of these aspects may lead to biased views and misleading evaluations of this practice. To our knowledge, a few studies have conducted short-term (only during the rice-growing season) measurements of $\mathrm{CH}_{4}$ and $\mathrm{N}_{2} \mathrm{O}$ fluxes under GCRPS (Dittert et al., 2002; Xu et al., 2004; Kreye et al., 2007), but so far no study available has quantified the effects of GCRPS on the net greenhouse effects at the annual scale.

In response to these research needs, we launched a case study in which $\mathrm{CH}_{4}$ and $\mathrm{N}_{2} \mathrm{O}$ fluxes, soil respiration $\left(\mathrm{CO}_{2}\right)$ emissions and rice yields were measured simultaneously in an annual rice-based cropping system under conventional paddy and GCRPS practices. The main objectives of this study were to (a) characterize and quantify the $\mathrm{CH}_{4}, \mathrm{~N}_{2} \mathrm{O}$ and $\mathrm{CO}_{2}$ fluxes and the direct emission factors of fertilizer $\mathrm{N}$ across the annual rice-fallow systems, (b) better understand the key regulating factors on $\mathrm{CH}_{4}, \mathrm{~N}_{2} \mathrm{O}$ and $\mathrm{CO}_{2}$ fluxes from two contrasting practices, and (c) assess the efficacy of watersaving GCRPS technique to minimize the net greenhouse effects while sustaining crop yield.

\section{Materials and methods}

\subsection{Site description and field experiment}

Our field measurements were performed in paddy fields $\left(32^{\circ} 38^{\prime} \mathrm{N}, 110^{\circ} 37^{\prime} \mathrm{E}\right.$, approx. $234 \mathrm{~m}$ above sea level) in the city of Shiyan, Hubei province, central China, where GCRPS was introduced in the 1990s and is now widely applied by local farmers because of water and temperature limitations for rice cultivation (Zhou et al., 2008). The field site is on the bottom of a small valley, which is lo- cated in a typical hilly agricultural area, where cropping regime is primarily dominated by annual rice paddy-fallow system. The region is exposed to the northern subtropical monsoon climate, with an annual mean air temperature of $15.3^{\circ} \mathrm{C}$, an annual average rainfall of $834 \mathrm{~mm}$, an annual total sunshine of $1835 \mathrm{~h}$ and a frost-free period of 234 days. The topsoil $(0-15 \mathrm{~cm})$ of the experimental farm is of a sandy loam texture with $5.2 \pm 0.7 \%$ clay $(<0.002 \mathrm{~mm})$, $33.7 \pm 2.5 \%$ silt $(0.002-0.02 \mathrm{~mm})$ and $61.1 \pm 3.2 \%$ sand $(0.02-2 \mathrm{~mm})$; it has a $\mathrm{pH}$ value of 6.2 , an organic carbon content of $10.3 \pm 1.3 \mathrm{~g} \mathrm{~kg}^{-1}$, total nitrogen content of $1.18 \pm 0.07 \mathrm{~g} \mathrm{~kg}^{-1}$ and a bulk density of $1.30 \pm 0.04 \mathrm{~g} \mathrm{~cm}^{-3}$. As a result of long-term conventional tillage practices, soils at the field site have developed a compact plough pan layer at approximately $20 \mathrm{~cm}$ depth, which may substantially inhibit water infiltration while favoring lateral flow.

In the present study, we investigated six fertilizer treatments under the two rice production systems (Table 1): two fertilizer treatments for the conventional paddy (i.e., CNN: no nitrogen fertilization as a control and CUN: urea applied at a common rate) and four fertilizer treatments in GCRPS (i.e., GNN: no nitrogen fertilization as a control, GUN: urea applied at a common rate, GCM: chicken manure applied at a common $\mathrm{N}$ rate, and GUM: urea plus chicken manure at $1: 1$ nitrogen basis). Since our previous studies in the Jiangsu province showed that the use of organic matter in conventional paddy rice production systems leads to increased net GHG emissions (Yao et al., 2013a), only the treatments with urea application and the control were established for the conventional paddy (i.e., CNN and CUN). The treatments were arranged in a completely randomized block design with three replications (each plot with a size of $5 \mathrm{~m} \times 8 \mathrm{~m}$ ), giving a total of 18 plots. All plots were completely isolated by levees 
with plastic coverings. The total $\mathrm{N}$ content and $\mathrm{C}: \mathrm{N}$ ratio of the applied chicken manure were $1 \%$ and 13.6 , respectively. Fertilizer, organic, inorganic or a mix of both, was applied once as basal fertilization at a rate of $150 \mathrm{~kg} \mathrm{Nha}^{-1}$ just before rice transplanting. In addition, all treatments received $45 \mathrm{~kg} \mathrm{P}_{2} \mathrm{O}_{5} \mathrm{ha}^{-1}$ and $45 \mathrm{~kg} \mathrm{~K}_{2} \mathrm{Oha}^{-1}$ as basal fertilizers in the forms of $\mathrm{Ca}\left(\mathrm{H}_{2} \mathrm{PO}_{4}\right)_{2}$ and $\mathrm{KCl}$, respectively. In agreement with the local water regime, the experimental plots of conventional paddy were under a cycle of flooding/midseason drainage/frequent waterlogging with intermittent irrigation (F-D-F). In the present study, the mid-season drainage started on 25 June and ended on 30 June, and the period of final drainage was from 11 August to the end of rice-growing season (Fig. 1). For GCRPS, to realize the goal of saving water and simultaneously satisfying rice growth, each plot was further separated into three raised beds (width 1.4 and length $7.6 \mathrm{~m}$ ) surrounded by 0.2 wide and $0.15 \mathrm{~m}$ deep furrows that were filled with water to maintain soil water content near saturation. Each raised bed in GCRPS was covered with a $0.005 \mathrm{~mm}$ thick and $1.7 \mathrm{~m}$ wide transparent polyethylene plastic film, and then holes were punched in plastic film using a special puncher for the transplantation of rice seedlings. In the GCRPS plots, irrigation was applied in the furrows only to keep soil moist with no standing water on the raised beds. It should be noted that when the mid-season and final drainage were practiced in the conventional paddy, irrigation was also not applied in the GCRPS during these periods. After rice harvest, the rice straw was completely harvested and removed and all field plots were kept fallow over the winter period. During the fallow period, the local farmers usually collected the plastic film from the GCRPS plots, and then plowed all of the experimental fields to control weeds and insects.

\subsection{Measurements of GHGs fluxes}

The $\mathrm{CH}_{4}$ and $\mathrm{N}_{2} \mathrm{O}$ fluxes along with soil $\mathrm{CO}_{2}$ emissions were measured in situ using static opaque manual gas sampling chambers (Yao et al., 2009) over the entire rice-fallow rotation under conventional paddy and GCRPS practices from May 2011 to April 2012. During the rice-growing season, to better evaluate the $\mathrm{CH}_{4}$ and $\mathrm{N}_{2} \mathrm{O}$ fluxes under GCRPS, two sizes of rectangular stainless-steel frames of $0.65 \mathrm{~m}$ width $\times 0.90 \mathrm{~m}$ length $\times 0.15 \mathrm{~m}$ height and $0.20 \mathrm{~m}$ width $\times 0.30 \mathrm{~m}$ length $\times 0.20 \mathrm{~m}$ height were inserted into the soils of the raised bed and furrow, respectively, before rice transplanting in each plot. In order to keep conditions inside the frame as similar to the actual field status of the raised bed in GCRPS, the soil inside the frame was also covered by plastic film with two rows of transplanting holes with a diameter of $3 \mathrm{~cm}$ every $16 \mathrm{~cm}$ along the raised bed. The top edge of the frame had a water groove, which fit exactly to the rim of the top chamber, and the gas-tight seal was ensured by filling the groove with water. For the conventional paddy, only one frame of $0.65 \mathrm{~m}$ width $\times 0.90 \mathrm{~m}$ length $\times 0.15 \mathrm{~m}$ height

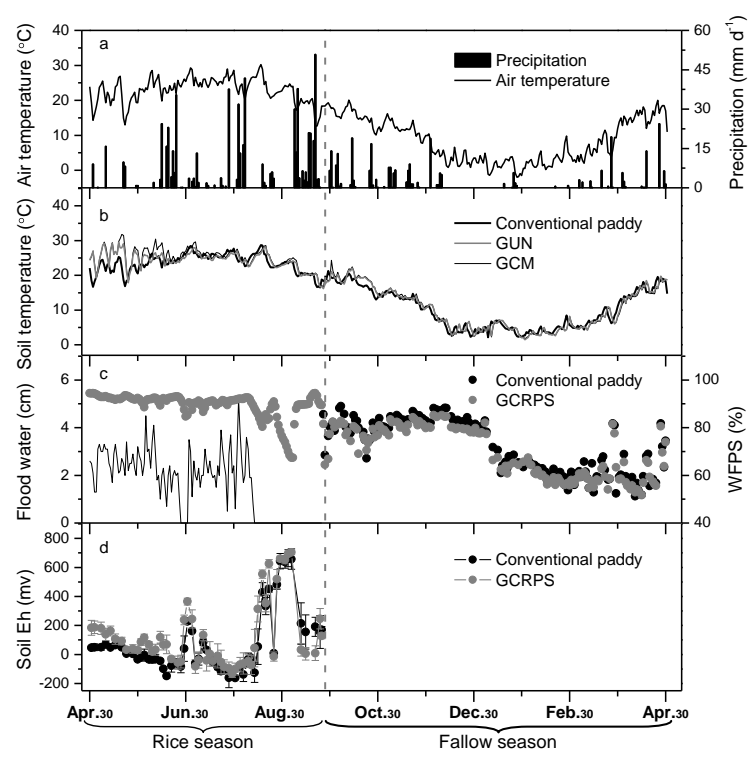

Figure 1. The dynamics of (a) daily precipitation and mean air temperature, (b) daily mean soil temperature for the conventional paddy and ground cover rice production system (GCRPS) with urea (GUN) and chicken manure (GCM) applications, (c) floodwater depth during the rice-growing season for the conventional paddy and water-filled pore space (WFPS) at $0-6 \mathrm{~cm}$ soil depth and (d) soil redox potential ( $E_{\mathrm{h}}$, mean \pm standard error) at a depth of $10 \mathrm{~cm}$ for the conventional paddy and GCRPS during the rice-fallow rotation cycle of 2011-2012.

was put into the soil for each plot. To assess $\mathrm{CO}_{2}$ emissions from the bare soils of conventional paddy and GCRPS plots, a square stainless-steel frame with an area of $0.25 \mathrm{~m}^{2}$ was driven into the soil to a depth of $0.40 \mathrm{~m}$ so as to inhibit outside root access, and maintained the bare soil inside throughout the rice-growing season. Based on the types of frames, three different sizes of insulated chambers (i.e., with a bottom area of $0.65 \mathrm{~m} \times 0.90 \mathrm{~m}$ and a height of 0.50 or $1.0 \mathrm{~m}$ depending on crop growth, a $0.20 \mathrm{~m}$ width $\times 0.30 \mathrm{~m}$ length $\times 0.30 \mathrm{~m}$ height, and a bottom area of $0.50 \mathrm{~m} \times 0.50 \mathrm{~m}$ and a height of $0.50 \mathrm{~m}$ ) were used for gas samplings. These chambers were covered with reflective material to (i.e., foil) reduce absorption of sunlight and had a hole of $2 \mathrm{~cm}$ diameter in the top panel for equilibrating the pressure during the placement of them on the water groove of frames. This hole was kept closed during the air sampling by using a pressure balance tube which was determined in terms of the description of Hutchinson and Mosier (1981). During the fallow period, the frames both in the furrows and in the bare soils were removed because all field plots were drained and kept bare. That is, only one size of frame with width $0.65 \mathrm{~m} \times$ length $0.90 \mathrm{~m} \times$ height $0.15 \mathrm{~m}$ was maintained in place throughout the fallow season, except when it was removed for tillage on 4 January 2012, and thus, the fluxes of $\mathrm{CH}_{4}, \mathrm{~N}_{2} \mathrm{O}$ and $\mathrm{CO}_{2}$ were measured from the same chambers during the fallow period. 
On each sampling day, chambers were temporarily mounted onto the frames, and gas samples for $\mathrm{CH}_{4}, \mathrm{~N}_{2} \mathrm{O}$ and $\mathrm{CO}_{2}$ detection were taken with a $60 \mathrm{~mL}$ polypropylene syringe at $0,10,20,30$ and $40 \mathrm{~min}$ after covering. During the gas collection, the air temperature inside the chamber was monitored using a digital thermometer (JM624, Tianjin Jinming Instrument Co. Ltd., China). Within 6 hr after gas sampling, gas samples were simultaneously analyzed for $\mathrm{CO}_{2}$, $\mathrm{CH}_{4}$ and $\mathrm{N}_{2} \mathrm{O}$ using a gas chromatograph (Agilent 7890A, Agilent Technologies, CA, USA) equipped with an electron capture detector for $\mathrm{N}_{2} \mathrm{O}$ detection and a flame ionization detector for $\mathrm{CH}_{4}$ and $\mathrm{CO}_{2}$ detection (a nickel catalyst applied for converting $\mathrm{CO}_{2}$ to $\mathrm{CH}_{4}$ ). A detailed description of the gas chromatograph configurations adopted in our instrument can be found in Zheng et al. (2008) and Wang et al. (2010). The fluxes of $\mathrm{CH}_{4}, \mathrm{~N}_{2} \mathrm{O}$ and $\mathrm{CO}_{2}$ were calculated from the linear or nonlinear changes in the gas concentrations in the enclosed chamber with time (Wang et al., 2013), and corrected for the height of chamber, chamber air temperature and ambient air pressure effects.

Generally, gas fluxes were measured between 8:00 and 11:00 LT in the morning, assuming that the fluxes at that time represent the approximate daily mean of GHGs fluxes since the soil temperature during that period was close to the average daily soil temperature (Yao et al., 2009). Over the ricegrowing season, flux measurements were usually done three to four times per week at intervals of 1 to 2 days, whereas during the fallow period flux measurements were done five times per week.

\subsection{Auxiliary measurements}

At times of GHGs flux measurements, soil $E_{\mathrm{h}}$ at a depth of $10 \mathrm{~cm}$ were monitored using platinum-tipped electrodes with a calomel reference electrode connected to a portable millivolt meter (FJA-5, Nanjing Chuan-Di Instrument Co. Ltd., China). Each of the 18 plots had two replicated electrodes that were permanently installed in the experimental fields during the rice-growing period. Over the rice-growing season, soil water contents in the GCRPS plots were automatically measured in 30 min intervals using a frequency domain reflectometry (FDR) sensor (RDS Technology Co., Ltd Jiangsu, Nanjing, China). The FDR probes were embedded in the soil layer $(0-6 \mathrm{~cm})$ before rice transplanting. For the conventional paddy plots, the field floodwater depth was monitored daily using an embedded vertical ruler. For the fallow period, soil $(0-6 \mathrm{~cm})$ moisture in all field plots was measured daily adjacent to the frames by using a portable FDR probe. Over the entire rice-fallow system, the air temperature and daily precipitation were recorded by an automatic meteorological station (HOBO, Onset, USA) at the experimental farm. Soil $(5 \mathrm{~cm})$ temperature in the conventional paddy and GCRPS plots was automatically recorded in 15 min intervals using a $\mathrm{HOBO}$ temperature sensor (Onset, USA). To determine soil mineral $\mathrm{N}\left(\mathrm{NH}_{4}^{+}\right.$and $\left.\mathrm{NO}_{3}^{-}\right)$ and dissolved organic $\mathrm{C}$ (DOC) contents, soil samples at a depth of $0-10 \mathrm{~cm}$ were randomly collected at two points in each plot using a $3 \mathrm{~cm}$ diameter gauge auger at weekly intervals. Following the collection, soil samples were bulked for each treatment, and extracted using $1 \mathrm{M} \mathrm{KCl}$ solution for $\mathrm{NH}_{4}^{+}$and $\mathrm{NO}_{3}^{-}$determination and using $0.05 \mathrm{M} \mathrm{K}_{2} \mathrm{SO}_{4}$ solution for DOC measurement. The soil extracts were frozen at $-18^{\circ} \mathrm{C}$ and later analyzed with a continuous flow analyzer instrument (San++, Skalar Analytical B.V., the Netherlands) for simultaneous measurements of $\mathrm{NH}_{4}^{+}, \mathrm{NO}_{3}^{-}$and DOC.

The rice plants at physiological maturity were harvested manually from one subplot with a size of $1.4 \mathrm{~m} \times 7.6 \mathrm{~m}$ in each experimental plot, and then separated into grain and straw. The yields of grain and straw were determined after oven drying at $70^{\circ} \mathrm{C}$ to a constant weight, and then each part was further processed and analyzed for $\mathrm{C}$ and $\mathrm{N}$ content $(\mathrm{Qu}$ et al., 2012). In order to determine the weight of root at maturity, all rice plants (including aboveground biomass and root until $40 \mathrm{~cm}$ soil depth) at eight randomly selected hills (approximately $0.3 \mathrm{~m}^{2}$ ) were harvested in each plot, washed and separated for aboveground and belowground biomass and dried to a constant weight.

\subsection{Data processing and statistical analysis}

The fluxes of $\mathrm{CH}_{4}, \mathrm{~N}_{2} \mathrm{O}$ and $\mathrm{CO}_{2}$ for each treatment of a given sampling date were obtained by averaging fluxes of the three spatial replicates. The total cumulative fluxes of an individual gas over the rice season, fallow period and annual rotation cycle were directly calculated from the observed fluxes, using linear interpolation between sampling dates. The $\mathrm{N}_{2} \mathrm{O}$ emission factor of fertilizer $\mathrm{N}$ applied to the soil was computed by subtracting the total cumulative emission of $\mathrm{N}_{2} \mathrm{O}$ in the control from the corresponding total emissions in each fertilized treatment and dividing the result by the applied total amount of $\mathrm{N}$ fertilization. To assess the combined climatic impact from $\mathrm{CH}_{4}$ and $\mathrm{N}_{2} \mathrm{O}$ under the agronomic treatments, the aggregate emissions of $\mathrm{CH}_{4}$ and $\mathrm{N}_{2} \mathrm{O}$ (expressed in $\mathrm{CO}_{2}$ equivalents) were calculated using the global warming potential indices of 25 and 298 for $\mathrm{CH}_{4}$ and $\mathrm{N}_{2} \mathrm{O}$, respectively, over a 100-year time horizon (IPCC, 2007).

As the net ecosystem exchanges (NEEs) of $\mathrm{CO}_{2}$ during the rice-growing season could not be measured with the opaque chamber method, they were estimated from the difference between net primary production (NPP) and heterotrophic respiration $\left(R_{\mathrm{h}}\right)$ as suggested by Liu and Greaver (2009), i.e., $\mathrm{NEE}=R_{\mathrm{h}}-\mathrm{NPP}$, in which the NPP was determined by summing up the weights of harvested aboveground biomass (including straw and grain) and root, and the $R_{\mathrm{h}}$ was estimated as the soil respiration from the bare soil (Raich and Tufekcioglu, 2000). The carbon sequestration capacity of the soil was calculated by integrating NEE estimates, the amount of carbon incorporated through fertilization and the carbon amount harvested in the straw and grain, i.e., soil carbon sequestration capacity $\left(\mathrm{MgCha}^{-1}\right)=-\mathrm{NEE}+$ Incorporated 
Table 2. Straw $(S)$ and grain $(G)$ yields as well as total $(T)$ yields (straw and grain, in $\mathrm{Mg} \mathrm{ha}^{-1}$ ), and plant uptake of $\mathrm{C}$ (in $\mathrm{Mg}$ ha ${ }^{-1}$ ) and $\mathrm{N}$ (in $\mathrm{kg} \mathrm{ha}^{-1}$ ) at physiological maturity for different fertilizer treatments in the conventional paddy and ground cover rice production systems (GCRPS).

\begin{tabular}{|c|c|c|c|c|c|c|}
\hline & \multicolumn{2}{|c|}{ Conventional paddy } & \multicolumn{4}{|c|}{ GCRPS } \\
\hline & $\mathrm{CNN}$ & CUN & GNN & GUN & GCM & GUM \\
\hline Straw yield & $5.50 \pm 0.21 \mathrm{a}$ & $8.35 \pm 0.36 b c$ & $5.75 \pm 0.46 \mathrm{a}$ & $8.69 \pm 0.45 c$ & $6.17 \pm 0.52 \mathrm{ad}$ & $7.32 \pm 0.47 \mathrm{bd}$ \\
\hline$S$ uptake of C & $2.19 \pm 0.07 \mathrm{a}$ & $3.33 \pm 0.11 b c$ & $2.24 \pm 0.17 \mathrm{a}$ & $3.52 \pm 0.19 \mathrm{c}$ & $2.44 \pm 0.19 \mathrm{a}$ & $2.95 \pm 0.18 b$ \\
\hline$S$ uptake of N & $24.6 \pm 2.9 \mathrm{a}$ & $64.4 \pm 3.6 b$ & $29.9 \pm 2.2 \mathrm{a}$ & $66.5 \pm 7.8 b$ & $50.2 \pm 4.1 \mathrm{c}$ & $48.1 \pm 2.7 \mathrm{c}$ \\
\hline Grain yield & $5.49 \pm 0.17 \mathrm{a}$ & $7.92 \pm 0.21 b$ & $6.05 \pm 0.06 c$ & $7.70 \pm 0.19 b$ & $7.43 \pm 0.15 b$ & $7.97 \pm 0.16 b$ \\
\hline$G$ uptake of C & $2.34 \pm 0.07 \mathrm{a}$ & $3.41 \pm 0.09 b$ & $2.58 \pm 0.02 \mathrm{c}$ & $3.33 \pm 0.08 b$ & $3.22 \pm 0.05 b$ & $3.46 \pm 0.08 b$ \\
\hline$G$ uptake of N & $48.2 \pm 4.0 \mathrm{a}$ & $81.5 \pm 4.0 \mathrm{~b}$ & $61.8 \pm 1.9 \mathrm{c}$ & $87.7 \pm 3.6 b$ & $94.2 \pm 4.1 b$ & $93.9 \pm 5.7 b$ \\
\hline Total yield & $10.99 \pm 0.34 \mathrm{a}$ & $16.27 \pm 0.56 b$ & $11.80 \pm 0.40 \mathrm{a}$ & $16.39 \pm 0.43 b$ & $13.60 \pm 0.60 c$ & $15.29 \pm 0.63 b$ \\
\hline$T$ uptake of C & $4.52 \pm 0.13 \mathrm{a}$ & $6.74 \pm 0.20 b$ & $4.82 \pm 0.15 \mathrm{a}$ & $6.84 \pm 0.17 b$ & $5.67 \pm 0.24 \mathrm{c}$ & $6.40 \pm 0.26 b$ \\
\hline$T$ uptake of $\mathrm{N}$ & $72.8 \pm 6.9 \mathrm{a}$ & $145.9 \pm 3.3 b$ & $91.6 \pm 4.0 \mathrm{a}$ & $154.2 \pm 8.9 b$ & $144.4 \pm 7.9 b$ & $141.9 \pm 5.2 b$ \\
\hline
\end{tabular}

Data shown are means \pm standard errors of three spatial replicated plots. Definitions of abbreviations for the different fertilizer treatments are shown in the footnotes of Table 1 and in the text. Different letters within the same row indicate statistically significant differences among treatments at the $P<0.05$ level.

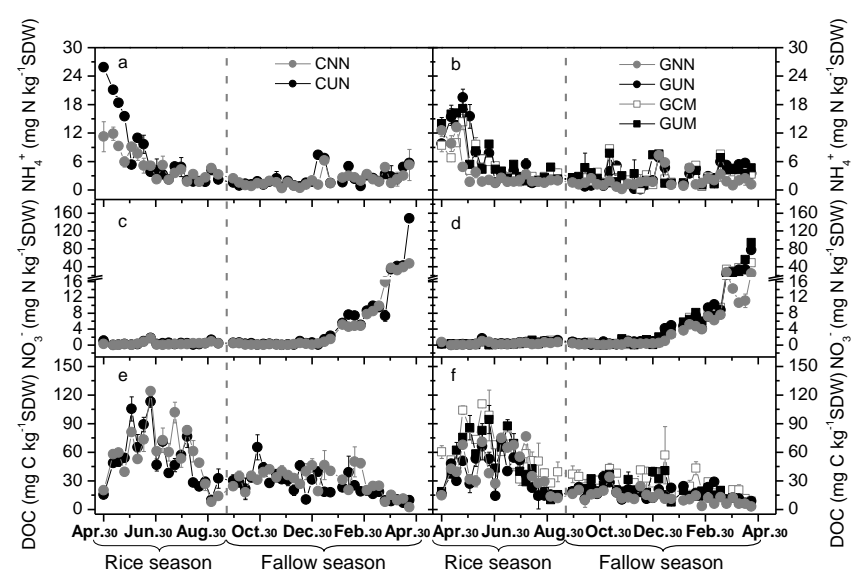

Figure 2. Seasonal dynamics in (a-b) soil ammonium $\left(\mathrm{NH}_{4}^{+}\right)$, (c-d) nitrate $\left(\mathrm{NO}_{3}^{-}\right)$and (e-f) dissolved organic carbon (DOC) contents (mean \pm standard error) for different fertilizer treatments in the conventional paddy and ground cover rice production systems during the rice-fallow rotation cycle of 2011-2012. SDW stands for soil dry weight. Definitions of abbreviations for the different fertilizer treatments are shown in the footnotes of Table 1 and in the text.

$\mathrm{C}-$ Harvested $\mathrm{C}$. Here the negative NEE fluxes indicate net $\mathrm{CO}_{2}$ uptake, and the negative values of carbon sequestration capacity indicate the net carbon losses from soil. It should be noted that our present estimates of soil carbon sequestration capacity were quite preliminary and exhibited a certain degree of underestimation due to not including root exudates. To calculate the complete GHG balance for conventional paddy and GCRPS treatments, the net ecosystem greenhouse gas exchange (NEGE) was estimated by integrating the $\mathrm{CH}_{4}$ and $\mathrm{N}_{2} \mathrm{O}$ fluxes and soil carbon sequestration capacity, i.e., NEGE $\left(\mathrm{MgCO}_{2}\right.$-eq ha $\left.{ }^{-1}\right)=25 \times \mathrm{CH}_{4}$ flux $\left(\mathrm{kgCha}^{-1}\right) \times 16 / 12 /$
$1000+298 \times \mathrm{N}_{2} \mathrm{O}$ flux $\left(\mathrm{kg} \mathrm{N} \mathrm{ha}^{-1}\right) \times 44 / 28 / 1000-$ soil C sequestration $\left(\mathrm{MgCha}^{-1}\right) \times 44 / 12$. In this study, the negative value of NEGE indicates the net sink of atmospheric GHGs.

All statistical analyses were performed using SPSS 12.0 (SPSS Inc., Chicago, USA) and Origin 7.0 (Origin Lab Corporation, USA). Differences in cumulative emissions from the rice-fallow system as affected by different agronomic treatments were examined by using a one-way ANOVA with Tukey's multiple range test. To estimate the relationships between soil environmental variables and GHGs emissions in the rice-growing season, multiple linear regression analyses were carried out with the stepwise procedure.

\section{Results}

\subsection{Environmental drivers and rice production}

The total amounts of rainfall were 597.8 and $281.2 \mathrm{~mm}$ for the rice and fallow seasons, respectively (Fig. 1a). Within the first two months after soil was covered by plastic film, soil temperature was $25.7^{\circ} \mathrm{C}$ on average in GCRPS but $22.8^{\circ} \mathrm{C}$ on average in the conventional paddy (Fig. 1b). Within the GCRPS plots, the chicken manure application generally increased soil temperature, with mean values of 24.3 and $25.2^{\circ} \mathrm{C}$ for GUN and GCM, respectively. During the fallow period, both conventional paddy and GCRPS showed comparable results of soil temperature (mean: 10.2 vs. $9.9^{\circ} \mathrm{C}$ ).

For the conventional paddy, a floodwater layer of on average $2.6 \pm 0.5 \mathrm{~cm}$ was maintained during the rice-growing season, except for the periods of mid-season aeration and final drainage. For GCRPS, soil water content was generally kept at more than $90 \%$ WFPS (water-filled pore space) until the final drainage before rice harvest (Fig. 1c). During the fallow period, there were no significant differences in soil water 


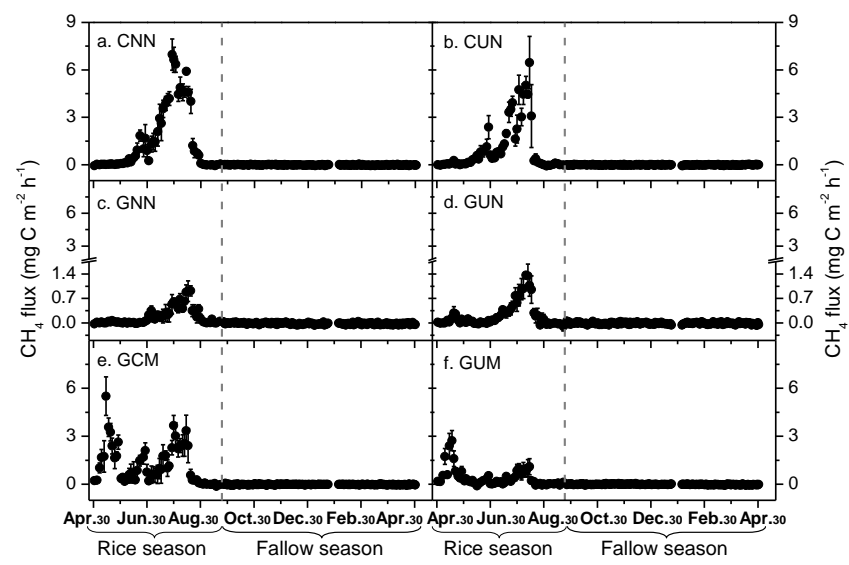

Figure 3. Seasonal dynamics in (a-f) methane $\left(\mathrm{CH}_{4}\right)$ fluxes (mean \pm standard error) for different fertilizer treatments in the conventional paddy and ground cover rice production systems during the rice-fallow rotation cycle of 2011-2012. The $\mathrm{CH}_{4}$ fluxes during the rice season as shown in panels $(\mathbf{c}-\mathbf{f})$ were measured from the raised beds of ground cover rice production systems. Definitions of abbreviations for the different fertilizer treatments are shown in the footnotes of Table 1 and in the text.

contents between GCRPS and conventional paddy. Both conventional paddy and GCRPS showed a comparable seasonality in soil $E_{\mathrm{h}}$ (Fig. 1d). However, soil $E_{\mathrm{h}}$ under GCRPS was on average $73 \%$ higher than that of conventional paddy.

Across the rice-growing season, the mean $\mathrm{NH}_{4}^{+}$content in the CNN (5.3 $\mathrm{mg} \mathrm{Ng}^{-1}$ SDW (soil dry weight)) and CUN (7.6 mg N kg${ }^{-1}$ SDW) treatments were 39 and $15 \%$ higher than that of the GNN and GUN, respectively (Fig. 2). In contrast, the seasonal mean $\mathrm{NO}_{3}^{-}$contents under $\mathrm{CNN}$ $\left(0.35 \mathrm{mg} \mathrm{N} \mathrm{kg}^{-1} \mathrm{SDW}\right)$ and CUN $\left(0.50 \mathrm{mg} \mathrm{N} \mathrm{kg}^{-1}\right.$ SDW $)$ were lower than their corresponding GNN and GUN treatments. Compared to the GUN, GCM reduced the $\mathrm{NH}_{4}^{+}$ and $\mathrm{NO}_{3}^{-}$contents by 20 and $28 \%$, respectively. Application of GUM increased soil $\mathrm{NH}_{4}^{+}$and $\mathrm{NO}_{3}^{-}$contents compared to GCM, but to a smaller extent than GUN. In addition, the mean DOC contents under conventional paddy (i.e., $57.9 \mathrm{mg} \mathrm{C} \mathrm{kg}^{-1} \mathrm{SDW}$ for CNN and $52.7 \mathrm{mg} \mathrm{C} \mathrm{kg}^{-1} \mathrm{SDW}$ for CUN) were higher than those of the GNN ( $43.1 \mathrm{mg} \mathrm{C} \mathrm{kg}^{-1}$ SDW) and GUN (36.6 $\mathrm{mg} \mathrm{C} \mathrm{kg}^{-1} \mathrm{SDW}$ ), but they were comparable to those of GUM and GCM. During the fallow period, all the fertilized treatments (CUN, GUN, GCM and GUM) had higher soil mineral $\mathrm{N}\left(\mathrm{NH}_{4}^{+}\right.$and $\left.\mathrm{NO}_{3}^{-}\right)$contents (11.8-14.1 $\left.\mathrm{mg} \mathrm{N} \mathrm{kg}^{-1} \mathrm{SDW}\right)$ as compared to the controls (6.7-9.8 $\mathrm{mg} \mathrm{N} \mathrm{kg}^{-1} \mathrm{SDW}$ ).

The total yields of straw and grain and the uptake of $\mathrm{C}$ and $\mathrm{N}$ by the plants in the fertilized plots were significantly higher compared to the unfertilized controls regardless of rice production system $(P<0.05$, Table 2$)$. Compared to the CNN, the GNN treatment significantly improved grain yields by $10 \%(P<0.05)$, though there was no significant difference in straw yields. In contrast, the grain yields did not dif-
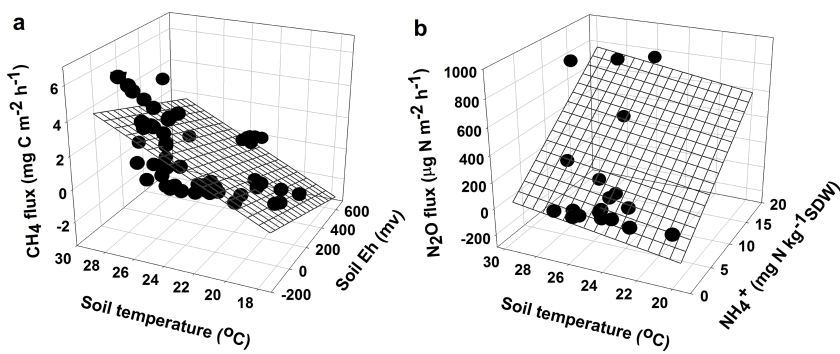

Figure 4. Relationships of (a) methane $\left(\mathrm{CH}_{4}\right)$ emissions to soil temperature and redox potential $\left(E_{\mathrm{h}}\right)$ in the control of conventional paddy rice production system (i.e., $\mathrm{CNN}$ ) and (b) nitrous oxide $\left(\mathrm{N}_{2} \mathrm{O}\right)$ emissions to soil temperature and ammonium $\left(\mathrm{NH}_{4}^{+}\right)$contents in the urea application treatment of ground cover rice production system (i.e., GUN) during the rice-growing season. The mesh plots are the result of multiple linear regression analysis according to the equations presented in Table 4 .

fer between CUN and GUN. The chicken manure amendments under GCRPS (GCM and GUM) did not influence grain yields, compared to CUN and GUN (Table 2).

\subsection{Methane fluxes}

During the rice-growing season, the $\mathrm{CH}_{4}$ emissions increased steadily after rice transplanting, and peak emissions were observed at the beginning of August for plots fertilized with urea (CUN and GUN) or left unfertilized (CNN and GNN). For plots fertilized with chicken manure (GCM and GUM), two periods with elevated $\mathrm{CH}_{4}$ emissions were observed: the first one appeared immediately following fertilization, while the second occurred at the beginning of August (Fig. 3). Seasonal cumulative $\mathrm{CH}_{4}$ emissions significantly varied by rice production system and fertilizer treatment (Table 3). Compared to the CNN, CUN significantly inhibited seasonal $\mathrm{CH}_{4}$ emissions by $33 \%(P<0.05)$. Under GCRPS, there were similar temporal trends but varying amplitudes of $\mathrm{CH}_{4}$ emissions between the furrow and raised bed of each treatment (Fig. 3 and Fig. S1 in the Supplement). Seasonal $\mathrm{CH}_{4}$ emissions for the furrows ranged from 2.07 to $3.67 \mathrm{~kg} \mathrm{Cha}^{-1}$, which was on average $72 \%$ lower than those of the raised beds $(P<0.05)$. The seasonal mean $\mathrm{CH}_{4}$ emissions under GCRPS, weighted by the areal extent of the furrow and raised bed, were 5.36, 6.65, 33.4 and $11.8 \mathrm{~kg} \mathrm{Cha}^{-1}$ for the GNN, GUN, GCM and GUM, respectively (Table 3). Averaging across GNN and GUN under GCRPS, the seasonal $\mathrm{CH}_{4}$ emission was $6.00 \pm 0.68 \mathrm{~kg} \mathrm{Cha}^{-1}$, which is $86 \%$ lower than that of the conventional paddy $(P<0.05)$, indicating that the conversion from conventional paddy to GCRPS inhibited $\mathrm{CH}_{4}$ emissions substantially. Also, the $\mathrm{CH}_{4}$ emissions from GCM and GUM under GCRPS were lower as compared to the conventional paddy.

Across sampling dates during the rice-growing season, $\mathrm{CH}_{4}$ emissions were negatively correlated with soil $E_{\mathrm{h}}$ and 
Table 3. Seasonal and annual cumulative fluxes of methane $\left(\mathrm{CH}_{4}\right.$, in $\left.\mathrm{kg} \mathrm{Cha}^{-1}\right)$ and nitrous oxide $\left(\mathrm{N}_{2} \mathrm{O}\right.$, in kg Nha $\left.{ }^{-1}\right)$ and direct emission factors of applied nitrogen (in \%) for different fertilizer treatments in the conventional paddy and ground cover rice production systems (GCRPS).

\begin{tabular}{|c|c|c|c|c|c|c|}
\hline & \multicolumn{2}{|c|}{ Conventional paddy } & \multicolumn{4}{|c|}{ GCRPS } \\
\hline & $\mathrm{CNN}$ & CUN & GNN & GUN & GCM & GUM \\
\hline \multicolumn{7}{|c|}{ Rice season } \\
\hline Raised bed $\mathrm{CH}_{4}$ & - & - & $6.19 \pm 0.64$ & $7.51 \pm 1.04$ & $41.1 \pm 0.98$ & $13.8 \pm 0.26$ \\
\hline Furrow $\mathrm{CH}_{4}$ & - & - & $2.07 \pm 0.29$ & $3.26 \pm 0.14$ & $3.09 \pm 0.38$ & $3.67 \pm 0.37$ \\
\hline Area weighted $\mathrm{CH}_{4}^{\mathrm{a}}$ & $52.3 \pm 3.8 \mathrm{a}$ & $35.2 \pm 4.6 b$ & $5.36 \pm 0.51 \mathrm{c}$ & $6.65 \pm 0.86 c$ & $33.4 \pm 0.85 b$ & $11.8 \pm 0.13 \mathrm{c}$ \\
\hline Raised bed $\mathrm{N}_{2} \mathrm{O}$ & - & - & $0.13 \pm 0.01$ & $5.12 \pm 1.2$ & $0.17 \pm 0.01$ & $0.40 \pm 0.07$ \\
\hline Furrow $\mathrm{N}_{2} \mathrm{O}$ & - & - & $0.070 \pm 0.01$ & $1.08 \pm 0.17$ & $0.089 \pm 0.01$ & $0.065 \pm 0.01$ \\
\hline Area weighted $\mathrm{N}_{2} \mathrm{O}^{\mathrm{a}}$ & $0.089 \pm 0.01 \mathrm{a}$ & $0.21 \pm 0.05 b$ & $0.12 \pm 0.01 \mathrm{ab}$ & $4.30 \pm 0.96 c$ & $0.15 \pm 0.01 \mathrm{ab}$ & $0.33 \pm 0.06 \mathrm{~d}$ \\
\hline Emission factor & - & 0.082 & - & 2.79 & 0.023 & 0.14 \\
\hline \multicolumn{7}{|c|}{ Fallow season } \\
\hline $\mathrm{CH}_{4}$ & $-0.54 \pm 0.25 \mathrm{a}$ & $-0.51 \pm 0.08 \mathrm{a}$ & $-0.92 \pm 0.13 \mathrm{a}$ & $-0.81 \pm 0.06 \mathrm{a}$ & $-0.84 \pm 0.06 \mathrm{a}$ & $-0.50 \pm 0.10 \mathrm{a}$ \\
\hline $\mathrm{N}_{2} \mathrm{O}$ & $0.45 \pm 0.02 \mathrm{a}$ & $2.60 \pm 0.75 b$ & $0.51 \pm 0.14 \mathrm{a}$ & $2.34 \pm 0.64 b c$ & $0.60 \pm 0.04 \mathrm{a}$ & $1.05 \pm 0.32 \mathrm{ac}$ \\
\hline \multicolumn{7}{|c|}{ Annual rotation } \\
\hline $\mathrm{CH}_{4}$ & $51.7 \pm 3.6 \mathrm{a}$ & $34.6 \pm 4.5 b$ & $4.43 \pm 0.61 \mathrm{c}$ & $5.84 \pm 0.89 \mathrm{c}$ & $32.6 \pm 0.89 b$ & $11.3 \pm 0.14 \mathrm{c}$ \\
\hline $\mathrm{N}_{2} \mathrm{O}$ & $0.54 \pm 0.02 \mathrm{a}$ & $2.81 \pm 0.80 \mathrm{~b}$ & $0.62 \pm 0.13 \mathrm{a}$ & $6.64 \pm 1.5 \mathrm{c}$ & $0.76 \pm 0.05 \mathrm{a}$ & $1.38 \pm 0.27 b$ \\
\hline Emission factor & - & 1.52 & - & 4.01 & 0.087 & 0.50 \\
\hline
\end{tabular}

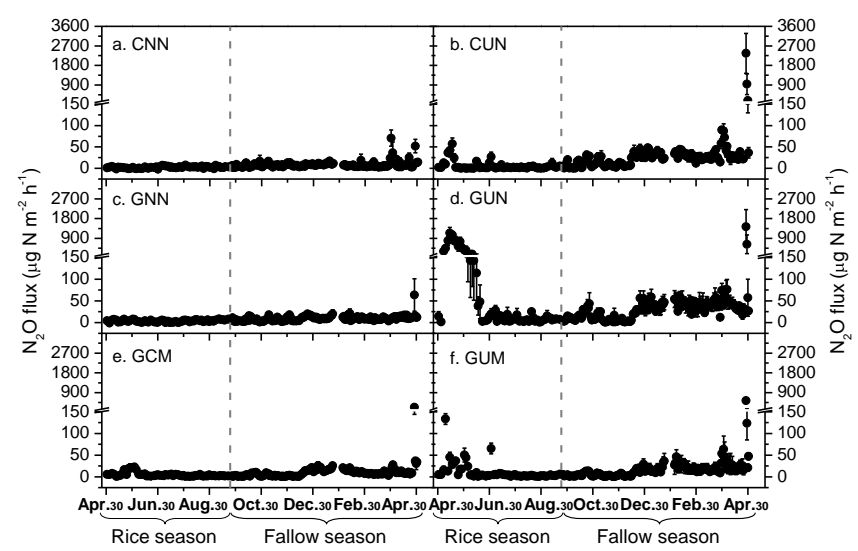

Figure 5. Seasonal dynamics in (a-f) nitrous oxide $\left(\mathrm{N}_{2} \mathrm{O}\right)$ fluxes (mean \pm standard error) for different fertilizer treatments in the conventional paddy and ground cover rice production systems during the rice-fallow rotation cycle of 2011-2012. The $\mathrm{N}_{2} \mathrm{O}$ fluxes during the rice season as shown in panels (c-f) were measured from the raised beds of ground cover rice production systems. Definitions of abbreviations for the different fertilizer treatments are shown in the footnotes of Table 1 and in the text.

positively with soil temperature (Table 4). For instance, soil temperature and $E_{\mathrm{h}}$ together explained approximately $46 \%$ of the observed temporal variation in $\mathrm{CH}_{4}$ emission for $\mathrm{CNN}$ (Fig. 4).
In the following fallow season, there were no significant production system impacts or seasonal patterns (Fig. S2 in the Supplement). Over the fallow period, soils of all treatments acted as weak sinks for atmospheric $\mathrm{CH}_{4}$, which ranged from -0.92 to $-0.50 \mathrm{~kg} \mathrm{Cha}^{-1}$ (Table 3). Annual $\mathrm{CH}_{4}$ emissions over the rice-fallow system ranged from $4.43 \mathrm{~kg} \mathrm{Cha}^{-1} \mathrm{yr}^{-1}$ for the GNN to $51.7 \mathrm{~kg} \mathrm{Cha}^{-1} \mathrm{yr}^{-1}$ for the CNN plots. Across the plots with urea application and the control, annual $\mathrm{CH}_{4}$ emission averaged 5.14 and $43.2 \mathrm{~kg} \mathrm{Cha}^{-1} \mathrm{yr}^{-1}$ for the GCRPS and conventional paddy, respectively; the former value was significantly lower than the latter one $(P<0.05$, Table 3$)$.

\subsection{Nitrous oxide emissions}

During the rice-growing season, the $\mathrm{N}_{2} \mathrm{O}$ emissions from the unfertilized plots (CNN and GNN) were consistently low (mean: $<8 \mu \mathrm{g} \mathrm{N} \mathrm{m}^{-2} \mathrm{~h}^{-1}$, Fig. 5). The $\mathrm{N}_{2} \mathrm{O}$ emissions from the fertilized plots (CUN, GUN, GCM and GUM) were relatively low and steady across the rice-growing season, apart from a pronounced peak following fertilization and a small spike following mid-season drainage at the end of June. Among all the fertilizer treatments, the highest peak emission of $\mathrm{N}_{2} \mathrm{O}$ appeared in the GUN plots, and $\mathrm{N}_{2} \mathrm{O}$ emissions remained much higher compared to the other treatments for almost 6 weeks following fertilization, although the emissions did fluctuate (Fig. 5). Similar to $\mathrm{CH}_{4}$ emission, seasonal $\mathrm{N}_{2} \mathrm{O}$ emissions were also affected by rice production system and 
Table 4. Stepwise multiple linear regression analysis between soil environmental variables and the emissions of methane $\left(\mathrm{CH}_{4}\right)$, nitrous oxide $\left(\mathrm{N}_{2} \mathrm{O}\right)$ and heterotrophic respiration $\left(\mathrm{CO}_{2}\right)$ for different fertilizer treatments during the rice-growing season.

\begin{tabular}{|c|c|c|c|c|}
\hline & Regression function $^{\mathrm{a}}$ & $R^{2^{\mathrm{b}}}$ & $P^{\mathrm{c}}$ & $\begin{array}{l}\text { Number } \\
\text { of cases }\end{array}$ \\
\hline \multicolumn{5}{|c|}{ Methane $\left(\mathrm{CH}_{4}\right)$} \\
\hline $\mathrm{CNN}$ & $F_{\mathrm{CH}_{4}}=-8.59-0.003 E_{\mathrm{h}}+0.44 \mathrm{ST}$ & 0.46 & $<0.01$ & 60 \\
\hline CUN & $F_{\mathrm{CH}_{4}}=-4.18-0.003 E_{\mathrm{h}}+0.23 \mathrm{ST}$ & 0.35 & $<0.01$ & 60 \\
\hline GNN & NS & NS & NS & \\
\hline GUN & NS & NS & NS & \\
\hline GCM & $F_{\mathrm{CH}_{4}}=1.38-0.003 E_{\mathrm{h}}$ & 0.29 & $<0.05$ & 60 \\
\hline GUM & $F_{\mathrm{CH}_{4}}=0.39-0.001 E_{\mathrm{h}}$ & 0.26 & $<0.05$ & 60 \\
\hline \multicolumn{5}{|c|}{ Nitrous oxide $\left(\mathrm{N}_{2} \mathrm{O}\right)$} \\
\hline $\mathrm{CNN}$ & NS & NS & NS & \\
\hline CUN & $F_{\mathrm{N}_{2} \mathrm{O}}=1.33+0.96 \mathrm{NH}_{4}^{+}$ & 0.22 & $<0.05$ & 20 \\
\hline GNN & NS & NS & NS & \\
\hline GUN & $F_{\mathrm{N}_{2} \mathrm{O}}=-569.3+41.6 \mathrm{NH}_{4}^{+}+17.6 \mathrm{ST}$ & 0.77 & $<0.01$ & 20 \\
\hline GCM & $F_{\mathrm{N}_{2} \mathrm{O}}=-9.80+0.58 \mathrm{ST}$ & 0.10 & $<0.05$ & 60 \\
\hline GUM & $F_{\mathrm{N}_{2} \mathrm{O}}=-25.3+0.84 \mathrm{NH}_{4}^{+}+1.01 \mathrm{ST}$ & 0.59 & $<0.01$ & 20 \\
\hline \multicolumn{5}{|c|}{ Heterotrophic respiration $\left(\mathrm{CO}_{2}\right)$} \\
\hline $\mathrm{CNN}$ & $F_{\mathrm{CO}_{2}}=26.0+0.088 E_{\mathrm{h}}$ & 0.46 & $<0.01$ & 20 \\
\hline CUN & $F_{\mathrm{CO}_{2}}=22.7+0.11 E_{\mathrm{h}}$ & 0.51 & $<0.01$ & 20 \\
\hline GNN & $F_{\mathrm{CO}_{2}}=320.6-3.27 \mathrm{WFPS}$ & 0.74 & $<0.01$ & 60 \\
\hline GUN & $F_{\mathrm{CO}_{2}}=328.1-3.39 \mathrm{WFPS}$ & 0.91 & $<0.01$ & 60 \\
\hline GCM & $F_{\mathrm{CO}_{2}}=293.3-2.94 \mathrm{WFPS}$ & 0.72 & $<0.01$ & 60 \\
\hline GUM & $F_{\mathrm{CO}_{2}}=251.2-2.52 \mathrm{WFPS}$ & 0.75 & $<0.01$ & 60 \\
\hline
\end{tabular}

${ }^{\mathrm{a}} \mathrm{F}$, the trace gas fluxes; $E_{\mathrm{h}}$, soil redox potential; ST, soil temperature; WFPS, water-filled pore space; NS, not significant.

${ }^{\mathrm{b}}$ Coefficient of determination. ${ }^{\mathrm{c}}$ Values indicate significance level. Definitions of abbreviations for the different fertilizer treatments are shown in the footnotes of Table 1 and in the text.

fertilizer treatment. Under conventional paddy, CUN significantly increased $\mathrm{N}_{2} \mathrm{O}$ emissions by $138 \%$ relative to the $\mathrm{CNN}(P<0.05)$, and the direct emission factor of $\mathrm{N}_{2} \mathrm{O}$ was estimated to be $0.082 \%$. For the GCRPS plots, the magnitude of $\mathrm{N}_{2} \mathrm{O}$ emissions from the furrows was significantly lower than from the raised beds $(P<0.05$, Table 3$)$, although they showed similar seasonal patterns (Figs. 5 and S1). The areaweighted seasonal $\mathrm{N}_{2} \mathrm{O}$ emissions were $0.12,4.30,0.15$ and $0.33 \mathrm{~kg} \mathrm{Nha}^{-1}$ for the GNN, GUN, GCM and GUM, respectively. The direct emission factors of $\mathrm{N}_{2} \mathrm{O}$ were estimated to be $2.79,0.023$ and $0.14 \%$ for the GUN, GCM and GUM, respectively. Across GNN and GUN under GCRPS, the seasonal $\mathrm{N}_{2} \mathrm{O}$ emission averaged $2.21 \mathrm{~kg} \mathrm{Nha}^{-1}$, which is remarkably higher than that of conventional paddy, indicating that the conversion from conventional paddy to GCRPS significantly stimulated $\mathrm{N}_{2} \mathrm{O}$ emissions. In contrast, GCM and GUM only slightly increased $\mathrm{N}_{2} \mathrm{O}$ emissions in comparison to the conventional paddy.

Across the rice-growing season, a positive linear correlation was found between $\mathrm{N}_{2} \mathrm{O}$ emissions and soil $\mathrm{NH}_{4}^{+}$contents or soil temperature, or both for all the fertilized treatments (Table 4). For example, Fig. 4b illustrates the relation- ship between soil temperature, $\mathrm{NH}_{4}^{+}$content and $\mathrm{N}_{2} \mathrm{O}$ emissions for the GUN.

During the fallow period, marked $\mathrm{N}_{2} \mathrm{O}$ emissions were recorded mainly in late March and April after substantial rainfall events (Figs. 1a and 5). Although no fertilizer was applied in the fallow season, the cumulative $\mathrm{N}_{2} \mathrm{O}$ emissions over this period were observed to be higher than those during the rice-growing season, except for the GUN treatment. Total $\mathrm{N}_{2} \mathrm{O}$ emissions in the fallow season (ranging from 0.45 to $2.60 \mathrm{~kg} \mathrm{Nha}^{-1}$ ) did not differ between the conventional paddy and GCRPS, but varied significantly among fertilizer treatments in each production system (Table 3 ).

Over the rice-fallow cropping cycle, annual $\mathrm{N}_{2} \mathrm{O}$ emissions ranged from $0.54 \mathrm{~kg} \mathrm{Nha}^{-1} \mathrm{yr}^{-1}$ for the CNN to $6.64 \mathrm{~kg} \mathrm{Nha}^{-1} \mathrm{yr}^{-1}$ for the GUN plots (Table 3). Although there was no significant difference in annual $\mathrm{N}_{2} \mathrm{O}$ emissions between CNN and GNN, GUN remarkably increased annual $\mathrm{N}_{2} \mathrm{O}$ emission by $136 \%$ relative to CUN $(P<0.05)$. In contrast, GUM did not significantly affect annual $\mathrm{N}_{2} \mathrm{O}$ emission, and GCM even reduced annual $\mathrm{N}_{2} \mathrm{O}$ emission by $73 \%$, compared to the CUN. The annual direct emission factor of $\mathrm{N}_{2} \mathrm{O}$ 


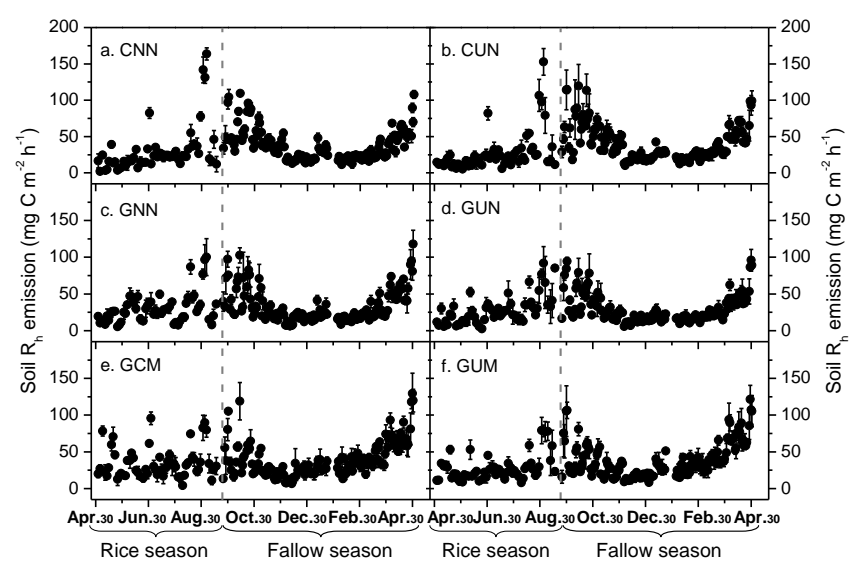

Figure 6. Seasonal dynamics in (a-f) soil heterotrophic respiration $\left(R_{\mathrm{h}}\right)$ emissions (mean \pm standard error) from bare soils of different fertilizer treatments in the conventional paddy and ground cover rice production systems during the rice-fallow rotation cycle of 2011-2012. Definitions of abbreviations for the different fertilizer treatments are shown in the footnotes of Table 1 and in the text.

was estimated to be $1.52,4.01,0.087$ and $0.50 \%$ for the CUN, GUN, GCM and GUM, respectively.

\subsection{Soil $\boldsymbol{R}_{\mathrm{h}}$ emissions and estimates of NEE and soil carbon sequestration}

Soil $R_{\mathrm{h}}$ emissions showed a slight peak in late August for the plots with urea application and the control (CNN, GNN, CUN and GUN). Similar results were observed in the GCM and GUM treatments, apart from a short flush following fertilization (Fig. 6). Over the rice-growing season, there were no significant differences in seasonal $R_{\mathrm{h}}$ emissions (ranging from 0.91 to $1.17 \mathrm{MgCha}^{-1}$ ) between the conventional paddy and GCRPS (Table 5). The soil $R_{\mathrm{h}}$ emission was significantly correlated with $E_{\mathrm{h}}$ under conventional paddy, while it was negatively correlated with WFPS under GCRPS (Table 4). For the rice growth period, the NEE fluxes ranged between -6.51 and $-3.97 \mathrm{MgC} \mathrm{ha}^{-1}$ for conventional paddy and from -6.68 to $-4.35 \mathrm{MgCha}^{-1}$ for GCRPS, with no significant difference between them (Table 5).

Soil $\mathrm{CO}_{2}$ emissions from the conventional paddy and GCRPS showed similar seasonal patterns during the fallow period (Fig. 6). The total $\mathrm{CO}_{2}$ emissions over this period ranged from 1.49 to $2.04 \mathrm{Mg} \mathrm{Cha}^{-1}$, with no significant effects of rice production system (Table 5). Over the entire rice-fallow system, the annual soil $\mathrm{CO}_{2}$ emissions and NEE fluxes ranged from 2.47 to $3.16 \mathrm{MgC} \mathrm{ha}^{-1} \mathrm{yr}^{-1}$ and -5.19 to $-2.06 \mathrm{MgCha}^{-1} \mathrm{yr}^{-1}$, respectively, among the treatments. There was no significant effects of rice production system on both annual soil $\mathrm{CO}_{2}$ emissions and NEE fluxes. The estimated annual soil carbon sequestration capacity ranged from $-2.47 \mathrm{Mg} \mathrm{Cha}^{-1} \mathrm{yr}^{-1}$ for $\mathrm{CNN}$ to $-0.44 \mathrm{Mg} \mathrm{Cha}^{-1} \mathrm{yr}^{-1}$ for GCM (Table 5). Across all treat- ments under GCRPS, the annual soil carbon sequestration capacity averaged $-1.33 \mathrm{MgC} \mathrm{ha}^{-1} \mathrm{yr}^{-1}$, which is $44 \%$ higher compared to the conventional paddy, indicating that the conversion from conventional paddy to GCRPS had the potential to reduce carbon loss from soil.

\subsection{Estimates of net ecosystem greenhouse gas exchange (NEGE)}

During the rice-growing season, total emissions of $\mathrm{CH}_{4}$ and $\mathrm{N}_{2} \mathrm{O}$ from GNN and GUN averaged $1235 \mathrm{~kg} \mathrm{CO}_{2}$-eq ha ${ }^{-1}$, which is approximately $19 \%$ lower than the conventional paddy (Table 5). The chicken manure applications under GCRPS, especially GCM, significantly reduced aggregate emissions of $\mathrm{CH}_{4}$ and $\mathrm{N}_{2} \mathrm{O}(P<0.05)$ compared to the CUN and GUN. During the fallow period, the aggregate emissions of $\mathrm{CH}_{4}$ and $\mathrm{N}_{2} \mathrm{O}$ did not significantly differ between the conventional paddy and GCRPS. Over the entire annual cycle, the mean total emissions of $\mathrm{CH}_{4}$ and $\mathrm{N}_{2} \mathrm{O}$ across GNN and GUN tended to be lower as compared to the conventional paddy. Relative to the CUN and GUN, GCM and GUM significantly reduced annual aggregate emissions of $\mathrm{CH}_{4}$ and $\mathrm{N}_{2} \mathrm{O}(P<0.05)$.

On the annual basis, the NEGE ranged from 3.05 for the GCM to $11.02 \mathrm{Mg} \mathrm{CO}_{2}$-eq ha ${ }^{-1}$ for the CNN plots (Table 5). There were no significant differences in annual NEGE between the urea application and the control, irrespective of rice production systems. Compared to the conventional paddy, the annual NEGE were reduced by $19 \%$ on average under GCRPS across GNN and GUN. The GCM and GUM treatments reduced annual NEGE by 67 and $47 \%$ in comparison with GUN, respectively, and by 72 and $54 \%$ relative to the CUN, respectively. Accordingly, the lowest NEGE was achieved under the GCM and GUM plots for the fertilized treatment (Table 5).

\section{Discussion}

\subsection{Key regulating factors of temporal variations of $\mathrm{CH}_{4}$ and $\mathrm{N}_{2} \mathrm{O}$ fluxes}

In the conventional paddy, a relatively low $\mathrm{CH}_{4}$ emission occurred before mid-season drainage and pronounced $\mathrm{CH}_{4}$ emissions were observed when the field was flooded again after the mid-season drainage (Fig. 3a-b). Our findings are inconsistent with the common pattern of $\mathrm{CH}_{4}$ emissions as reported by previous studies: steadily increasing $\mathrm{CH}_{4}$ emission until mid-season drainage, followed by a rapid decrease and no recovery of $\mathrm{CH}_{4}$ emission levels as compared to the pre-mid-season period until harvest (e.g., Cai et al., 1997; Nishimura et al., 2004; Zou et al., 2005a; Dong et al., 2011). This indicated that the $\mathrm{CH}_{4}$ emissions from hilly paddy fields could also be affected by the site-specific environmental factors such as soil temperature (Shang et al., 2011), apart from soil $E_{\mathrm{h}}$ which is used as an index for the oxidation-reduction 
Table 5. Net primary production (NPP) and soil heterotrophic respiration $\left(R_{\mathrm{h}}\right)$ and their estimated net ecosystem exchanges $(\mathrm{NEEs})$ of $\mathrm{CO}_{2}$, and the estimated $\mathrm{C}$ sequestration capacity in soil and aggregate emissions of $\mathrm{CH}_{4}$ and $\mathrm{N}_{2} \mathrm{O}$ and their estimated net ecosystem greenhouse gas exchanges (NEGE) for the conventional paddy and ground cover rice production systems under different fertilizer treatments over the annual rice-fallow cropping rotation.

\begin{tabular}{|c|c|c|c|c|c|c|c|c|}
\hline & $\begin{array}{r}\mathrm{NPP} \\
\left(\mathrm{MgCha}^{-1}\right)\end{array}$ & $\begin{array}{r}R_{\mathrm{h}} \\
\left(\mathrm{MgCha}^{-1}\right)\end{array}$ & $\begin{array}{r}\mathrm{NEE} \\
\left(\mathrm{MgCha}^{-1}\right)\end{array}$ & $\begin{array}{l}\text { Incorporated C } \\
\left(\mathrm{MgCha}^{-1}\right)\end{array}$ & $\begin{array}{l}\text { Harvested C } \\
\left(\mathrm{MgCha}^{-1}\right)\end{array}$ & $\begin{array}{l}\text { C sequestration } \\
\left(\mathrm{MgCha}^{-1}\right)\end{array}$ & $\begin{array}{l}\text { Aggregate emission of } \mathrm{CH}_{4} \\
\text { and } \mathrm{N}_{2} \mathrm{O}\left(\mathrm{kg} \mathrm{CO}_{2} \text {-eq ha }{ }^{-1}\right)\end{array}$ & $\begin{array}{r}\text { NEGE } \\
\left(\mathrm{Mg} \mathrm{CO}_{2} \text {-eq ha }{ }^{-1}\right)\end{array}$ \\
\hline \multicolumn{9}{|c|}{ Rice season } \\
\hline $\mathrm{CNN}$ & $4.98 \pm 0.14 \mathrm{a}$ & $1.00 \pm 0.01 \mathrm{ab}$ & $-3.97 \pm 0.14 \mathrm{a}$ & 0 & $4.52 \pm 0.13 \mathrm{a}$ & $-0.55 \pm 0.01 \mathrm{a}$ & $1785 \pm 125 \mathrm{ab}$ & $3.81 \pm 0.07 \mathrm{a}$ \\
\hline CUN & $7.42 \pm 0.22 b$ & $0.91 \pm 0.05 \mathrm{a}$ & $-6.51 \pm 0.23 b$ & 0 & $6.74 \pm 0.20 \mathrm{~b}$ & $-0.23 \pm 0.05 b$ & $1271 \pm 137 b$ & $2.13 \pm 0.13 b c$ \\
\hline GNN & $5.40 \pm 0.17 \mathrm{a}$ & $1.05 \pm 0.02 \mathrm{ab}$ & $-4.35 \pm 0.18 \mathrm{a}$ & 0 & $4.82 \pm 0.15 \mathrm{a}$ & $-0.47 \pm 0.03 \mathrm{a}$ & $234 \pm 19 \mathrm{c}$ & $1.97 \pm 0.13 c$ \\
\hline GUN & $7.67 \pm 0.19 b$ & $0.98 \pm 0.08 \mathrm{a}$ & $-6.68 \pm 0.25 b$ & 0 & $6.84 \pm 0.17 b$ & $-0.16 \pm 0.09 \mathrm{~b}$ & $2236 \pm 475 a$ & $2.83 \pm 0.52 b$ \\
\hline GCM & $6.35 \pm 0.27 b$ & $1.17 \pm 0.05 b$ & $-5.18 \pm 0.24 c$ & 2.04 & $5.67 \pm 0.24 b$ & $1.55 \pm 0.03 c$ & $1186 \pm 29 b$ & $-4.51 \pm 0.14 \mathrm{~d}$ \\
\hline GUM & $7.17 \pm 0.29 b$ & $0.96 \pm 0.07 \mathrm{a}$ & $-6.21 \pm 0.32 b$ & 1.02 & $6.40 \pm 0.26 b$ & $0.83 \pm 0.09 \mathrm{~d}$ & $546 \pm 30 c$ & $-2.51 \pm 0.31 \mathrm{~d}$ \\
\hline \multicolumn{9}{|c|}{ Fallow season } \\
\hline $\mathrm{CNN}$ & 0 & $1.91 \pm 0.03 \mathrm{a}$ & $1.91 \pm 0.03 \mathrm{a}$ & 0 & 0 & $-1.91 \pm 0.03 \mathrm{a}$ & $193 \pm 16 a$ & $7.21 \pm 0.10 \mathrm{a}$ \\
\hline CUN & 0 & $2.04 \pm 0.11 \mathrm{a}$ & $2.04 \pm 0.11 \mathrm{a}$ & 0 & 0 & $-2.04 \pm 0.11 \mathrm{a}$ & $1202 \pm 355 b$ & $8.67 \pm 0.44 b$ \\
\hline GNN & 0 & $1.67 \pm 0.05 \mathrm{ab}$ & $1.67 \pm 0.05 \mathrm{ab}$ & 0 & 0 & $-1.67 \pm 0.05 \mathrm{ab}$ & $207 \pm 62 \mathrm{a}$ & $6.33 \pm 0.13 a$ \\
\hline GUN & 0 & $1.49 \pm 0.14 b$ & $1.49 \pm 0.14 b$ & 0 & 0 & $-1.49 \pm 0.14 b$ & $1069 \pm 302 b c$ & $6.53 \pm 0.49 a$ \\
\hline GCM & 0 & $1.99 \pm 0.14 \mathrm{a}$ & $1.99 \pm 0.14 \mathrm{a}$ & 0 & 0 & $-1.99 \pm 0.14 \mathrm{a}$ & $254 \pm 19 a$ & $7.56 \pm 0.53 \mathrm{ab}$ \\
\hline GUM & 0 & $1.92 \pm 0.17 \mathrm{a}$ & $1.92 \pm 0.17 \mathrm{a}$ & 0 & 0 & $-1.92 \pm 0.17 \mathrm{a}$ & $475 \pm 150 \mathrm{ac}$ & $7.51 \pm 0.50 \mathrm{ab}$ \\
\hline \multicolumn{9}{|c|}{ Annual rotation } \\
\hline $\mathrm{CNN}$ & $4.98 \pm 0.14 \mathrm{a}$ & $2.92 \pm 0.03 \mathrm{ab}$ & $-2.06 \pm 0.16 \mathrm{a}$ & 0 & $4.52 \pm 0.13 a$ & $-2.47 \pm 0.04 \mathrm{a}$ & $1978 \pm 111 \mathrm{ad}$ & $11.02 \pm 0.07 \mathrm{a}$ \\
\hline CUN & $7.42 \pm 0.22 b$ & $2.94 \pm 0.15 \mathrm{ab}$ & $-4.47 \pm 0.25 b c$ & 0 & $6.74 \pm 0.20 b$ & $-2.27 \pm 0.15 \mathrm{a}$ & $2473 \pm 239 a c$ & $10.80 \pm 0.53 \mathrm{a}$ \\
\hline GNN & $5.40 \pm 0.17 \mathrm{a}$ & $2.72 \pm 0.05 \mathrm{ab}$ & $-2.67 \pm 0.13 \mathrm{ad}$ & 0 & $4.82 \pm 0.15 \mathrm{a}$ & $-2.14 \pm 0.03 \mathrm{ab}$ & $440 \pm 67 b$ & $8.30 \pm 0.11 b$ \\
\hline GUN & $7.67 \pm 0.19 b$ & $2.47 \pm 0.20 \mathrm{a}$ & $-5.19 \pm 0.28 \mathrm{c}$ & 0 & $6.84 \pm 0.17 b$ & $-1.65 \pm 0.22 b$ & $3305 \pm 713 c$ & $9.37 \pm 1.01 \mathrm{ab}$ \\
\hline GCM & $6.35 \pm 0.27 b$ & $3.16 \pm 0.19 b$ & $-3.19 \pm 0.22 \mathrm{~d}$ & 2.04 & $5.67 \pm 0.24 b$ & $-0.44 \pm 0.17 \mathrm{c}$ & $1440 \pm 45 \mathrm{~d}$ & $3.05 \pm 0.67 \mathrm{c}$ \\
\hline GUM & $7.17 \pm 0.29 b$ & $2.87 \pm 0.23 \mathrm{ab}$ & $-4.30 \pm 0.34 b$ & 1.02 & $6.40 \pm 0.26 b$ & $-1.09 \pm 0.22 \mathrm{~d}$ & $1022 \pm 123 d$ & $5.00 \pm 0.72 c$ \\
\hline
\end{tabular}

Data shown are means \pm standard errors of three spatial replicates. Definitions of abbreviations for the different fertilizer treatments are shown in the footnotes of Table 1 and in the text. Different letters within the same column indicate statistically significant differences among treatments during the periods of rice and fallow seasons as well as annual rotation.

conditions regulated by water management (Minamikawa and Sakai, 2005). It has been reported that low temperatures suppress $\mathrm{CH}_{4}$ fluxes (Castro et al., 1995), and thus, the low $\mathrm{CH}_{4}$ emission during the continuous flooding period before mid-season drainage indeed might be attributed to low soil temperatures at the start of the rice-growing period (on average $3{ }^{\circ} \mathrm{C}$ lower as compared to the paddy fields in Jiangsu province). This interpretation is further supported by the demonstrated correlations between $\mathrm{CH}_{4}$ emissions and soil $E_{\mathrm{h}}$ as well as soil temperature for the conventional paddy (Table 4 and Fig. 4a). The $\mathrm{CH}_{4}$ emissions in GCM and GUM under GCRPS were negatively correlated with soil $E_{\mathrm{h}}$ but not affected by soil temperature, highlighting the warming effect under GCRPS alleviating the hypothesized temperature limitation of methanogenesis. In contrast, we did not observe that the seasonality of $\mathrm{CH}_{4}$ emissions in GNN and GUN was affected by soil $E_{\mathrm{h}}$ or soil temperature, which is presumably due to the constantly low magnitude of $\mathrm{CH}_{4}$ emissions ( $\left.<1.0 \mathrm{mg} \mathrm{C} \mathrm{m}^{-2} \mathrm{~h}^{-1}\right)$ from these two treatments.

Under conventional paddy, periods of high $\mathrm{N}_{2} \mathrm{O}$ emissions were observed following $\mathrm{N}$ fertilization and mid-season drainage events, respectively (Fig. 5b). This is in agreement with previous studies (Cai et al., 1997; Zou et al., 2005a; Yao et al., 2010) and shows that availability of $\mathrm{N}$ substrates and changes in soil water regimes are the major drivers of high $\mathrm{N}_{2} \mathrm{O}$ emissions, which override the effect of soil temperature on nitrification and/or denitrification processes. However, the major regulating factors of $\mathrm{N}_{2} \mathrm{O}$ emissions in the fertilized treatments under GCRPS were soil $\mathrm{NH}_{4}^{+}$content and temperature (Table 4). These two regulating factors interacted positively (e.g., Fig. 4b) such that pronounced $\mathrm{N}_{2} \mathrm{O}$ emissions mostly occurred following fertilization coupled with the obvious warming effect of GCRPS, agreeing with the findings of previous research for comparable environments (e.g., Wang et al., 2011; Hu et al., 2013). In addition, during the fallow period, the $\mathrm{N}_{2} \mathrm{O}$ emissions in all the treatments remained low, and elevated emissions were only recorded in late March and April (Fig. 5) when heavy rainfall (> $27 \mathrm{~mm}$ ) increased the soil water content to approximately $\geq 80 \%$ WFPS (Fig. 1c). Similar rainfall driven peak emissions of $\mathrm{N}_{2} \mathrm{O}$ during the non-flooded period of rice-based cropping systems have been observed also in previous studies elsewhere (Zheng et al., 2000; Yao et al., 2010, 2013b) and further confirm that at soil water contents of 70-90\% WFPS pronounced $\mathrm{N}_{2} \mathrm{O}$ emissions are likely to occur (Dobbie et al., 1999; Wang et al., 2011).

\subsection{GCRPS and fertilizer practices affecting $\mathrm{CH}_{4}$ and $\mathrm{R}_{\mathrm{h}}$ fluxes}

Numerous studies report on $\mathrm{CH}_{4}$ emissions from rice paddies (e.g., Yagi et al., 1996; Sass et al., 1999; Yan et al., 
2009), but only a few studies measured $\mathrm{CH}_{4}$ and $\mathrm{N}_{2} \mathrm{O}$ fluxes simultaneously (e.g., Cai et al., 1997; Zou et al., 2005a; Linquist et al., 2012). To our knowledge, no study is available reporting annual fluxes of $\mathrm{N}_{2} \mathrm{O}, \mathrm{CH}_{4}$ and $\mathrm{CO}_{2}$ for GCRPS, even though the first measurements were done a decade ago (Dittert et al., 2002; Xu et al., 2004; Kreye et al., 2007). In this study, annual $\mathrm{CH}_{4}$ emissions under conventional paddy varied between 34.6 and $51.7 \mathrm{~kg} \mathrm{Cha}^{-1} \mathrm{yr}^{-1}$, which was within the lower ranges $\left(18-320 \mathrm{~kg} \mathrm{Cha}^{-1}\right)$ reported by Xie et al. (2010) for conventional Chinese paddy fields. In comparison to the $\mathrm{CNN}$, the urea application (CUN) significantly reduced annual $\mathrm{CH}_{4}$ emissions (Table 3). It is well accepted that synthetic $\mathrm{N}$ fertilizers increase crop growth as well as alter $\mathrm{CH}_{4}$ generating and oxidizing microbes, and thereby result in complex impacts on $\mathrm{CH}_{4}$ emissions (Bodelier and Laanbroek, 2004; Cai et al., 2007; Liu and Greaver, 2009). Banger et al. (2012) conducted a comprehensive meta-analysis on the net effects of $\mathrm{N}$ fertilizers on $\mathrm{CH}_{4}$ emission and found that in the majority of studies (98 of 155 data sets), $\mathrm{N}$ fertilization increased $\mathrm{CH}_{4}$ emissions from rice paddies. The effects of $\mathrm{N}$ fertilization will be modified by water management of rice paddies: under the conditions of intermittent irrigation with mid-season drainage, $\mathrm{N}$ fertilizers seem to stimulate methanotrophs leading to higher $\mathrm{CH}_{4}$ oxidation in the paddy fields (Banger et al., 2012). Also in this study, mid-season drainage which generally promotes aerobic soil conditions together with urea application obviously stimulated the $\mathrm{CH}_{4}$ oxidation activity in our soils and decreased $\mathrm{CH}_{4}$ emissions.

In comparison to the conventional paddy, on average, GCRPS across GNN and GUN decreased annual $\mathrm{CH}_{4}$ emissions substantially (Table 3 ). It is generally recognized that water management has a close relationship with the redox status of soil (e.g., Minamikawa and Sakai, 2005). Average soil $E_{\mathrm{h}}$ under GCRPS were significantly higher than that of the conventional paddy (Fig. 1d), indicating that under GCRPS more oxidized soil conditions prevailed during the rice-growing season. Accordingly, the GCRPS treatments with their more aerated soil conditions were likely to inhibit $\mathrm{CH}_{4}$ production by methanogens and favor $\mathrm{CH}_{4}$ consumption by methanotrophs, which integrally led to decreased $\mathrm{CH}_{4}$ emissions. Although the $\mathrm{CH}_{4}$ emissions under GCRPS were not affected by the urea application due to the negligible emissions from the GUN and GNN treatments, GCM significantly increased $\mathrm{CH}_{4}$ emissions (Table 3). It has long been shown that organic matter incorporation increases $\mathrm{CH}_{4}$ emissions from paddy fields due to the increased supply of C substrates and energy for methanogens (Bhattacharyya et al., 2012), which is further corroborated by the evidence that soil DOC contents were significantly higher in GCM.

In this study, the annual $R_{\mathrm{h}}$ emissions from all the treatments ranged from 2.47 to $3.16 \mathrm{MgCha}^{-1} \mathrm{yr}^{-1}$ (Table 5). These values were within the range of soil $R_{\mathrm{h}}$ emissions obtained in the global zone $\left(0.35\right.$ to $\left.2190 \mathrm{~g} \mathrm{C} \mathrm{m}^{-2} \mathrm{yr}^{-1}\right)$, as reported by Bond-Lamberty and Thomson (2010). It is worth noting that soil $R_{\mathrm{h}}$ emissions during the rice-growing season did not differ between conventional paddy and GCRPS, although GCRPS increased soil temperature. These results indicated that the nearly saturated soil water conditions under GCRPS might efficiently reduce the impact of soil temperature on $\mathrm{CO}_{2}$ emissions since the response of soil $\mathrm{CO}_{2}$ emission to increased temperature was likely constrained and masked by soil water content (Maestre and Cortina, 2003). Actually, our statistical analysis revealed that soil $\mathrm{CO}_{2}$ emissions under GCRPS were significantly correlated with WFPS, but were not affected by soil temperature (Table 4), which supports the above mentioned speculations. In addition, nutrients supplied via fertilization would be expected to influence soil $\mathrm{CO}_{2}$ emission by increasing rhizosphere $\mathrm{C}$ input due to enhanced plant productivity and root residue production (Iqbal et al., 2009). In this study, GCM generally increased annual soil $\mathrm{CO}_{2}$ emissions compared to GNN, which is consistent with other studies that organic amendments could enhance the bioavailability of soil $\mathrm{C}$ and microbial respiration (Lee et al., 2007; Bhattacharyya et al., 2012). In contrast, urea application did not affect soil microbial respiration (Table 5). In a review of more than 60 studies, Fog (1988) suggested that N fertilization showed no influence or a negative impact on decomposition of organic matter. Thus, one can reasonably speculate that soil $R_{\mathrm{h}}$ emissions did not differ between urea fertilization and control, since they are the net results of organic matter decomposition by soil microorganisms. Similarly, a number of previous studies also reported no difference in soil $\mathrm{CO}_{2}$ emission between control and synthetic $\mathrm{N}$ fertilizers (Rochette and Gregorich, 1998; Hu et al., 2004; Lee et al., 2007).

\subsection{GCRPS and fertilizer practices affecting $\mathrm{N}_{2} \mathrm{O}$ fluxes and direct emission factors}

For the conventional paddy, total $\mathrm{N}_{2} \mathrm{O}$ emissions during the rice-growing season were $0.089-0.21 \mathrm{~kg} \mathrm{Nha}^{-1}$, which is within the range of previously reported emissions (Akiyama et al., 2005). For the 53 studies considered in Akiyama et al. (2005) for paddy fields with mid-season drainage, $\mathrm{N}_{2} \mathrm{O}$ emissions ranging from 0.026 to $4.42 \mathrm{~kg} \mathrm{~N} \mathrm{ha}^{-1}$. Under GCRPS, total $\mathrm{N}_{2} \mathrm{O}$ emissions across the rice-growing period were $0.12-4.30 \mathrm{~kg} \mathrm{~N} \mathrm{ha}^{-1}$, which is comparable to previous estimates in water-saving paddy fields (Dittert et al., 2002; Kreye et al., 2007; Yang et al., 2012). It should be noted that although no fertilizer was applied in the following fallow season, cumulative $\mathrm{N}_{2} \mathrm{O}$ emissions over this period were up to $2.60 \mathrm{~kg} \mathrm{~N} \mathrm{ha}^{-1}$ (Table 3). This is likely a result of aerobic soil organic nitrogen mineralization during the upland fallow period, with associated productions of $\mathrm{N}_{2} \mathrm{O}$ from nitrification and denitrification (Liu et al., 2010; Shang et al., 2011). In addition, the $\mathrm{N}_{2} \mathrm{O}$ emissions during the fallow period tended to be higher in the fertilized than in the unfertilized plots (Table 3), showing that the effects of fertilization on $\mathrm{N}_{2} \mathrm{O}$ emissions is carried over into the following fallow period. This 
is also supported by the evidence that higher soil mineral $\mathrm{N}$ $\left(\mathrm{NH}_{4}^{+}\right.$and $\left.\mathrm{NO}_{3}^{-}\right)$contents were observed for the fertilized treatments during the fallow period (Fig. 2).

Annual $\mathrm{N}_{2} \mathrm{O}$ emissions and the urea-induced direct emission factor in the CUN plots were 58 and $62 \%$ lower than those of the GUN plots, respectively, which is largely due to increases in $\mathrm{N}_{2} \mathrm{O}$ emissions during the rice-growing season after conversion from conventional paddy to GCRPS (Table 3). Generally, the production of $\mathrm{N}_{2} \mathrm{O}$ in soils is greatly affected by soil water status and temperature (Williams et al., 1992; Smith et al., 2003; Schindlbacher et al., 2004). Under conventional paddy fields, nitrification of $\mathrm{NH}_{4}^{+}$was suppressed by a lack of oxidized soil conditions, and denitrification, which could be potentially produced in prevailing anaerobic conditions, was probably restricted by the high shortage of $\mathrm{NO}_{3}^{-}$or reacted completely (i.e., the reduction of $\mathrm{N}_{2} \mathrm{O}$ to $\mathrm{N}_{2}$ ), and thus, resulted in decreased $\mathrm{N}_{2} \mathrm{O}$ emissions. This explanation was supported by the higher $\mathrm{NH}_{4}^{+}$contents and at the same time, lower $\mathrm{NO}_{3}^{-}$contents for the CUN plots relative to the GUN plots (Fig. 2). In addition, the GUN treatment not only kept soil moisture at approximately $90 \%$ WFPS, but also increased soil temperature (Fig. 1), both favored the production and emission of $\mathrm{N}_{2} \mathrm{O}$.

Although GUN significantly increased $\mathrm{N}_{2} \mathrm{O}$ emissions, both GCM and GUM under GCRPS reduced annual $\mathrm{N}_{2} \mathrm{O}$ emissions substantially (Table 3 ). Similar inhibitory effects of organic fertilizer amendments on $\mathrm{N}_{2} \mathrm{O}$ emissions have been observed in other laboratory and field studies (Pathak et al., 2002; Yao et al., 2010; Qin et al., 2010). In contrast, some other studies observed that the incorporation of organic fertilizer stimulated $\mathrm{N}_{2} \mathrm{O}$ emissions or that $\mathrm{N}_{2} \mathrm{O}$ emissions were not affected at all (e.g., Gentile et al., 2008; Wang et al., 2011). In general, as was also observed in our study, the $\mathrm{N}_{2} \mathrm{O}$ emissions were highly dependent on soil mineral $\mathrm{N}\left(\mathrm{NH}_{4}^{+}\right.$ and $\mathrm{NO}_{3}^{-}$) availability in paddy fields (Liu et al., 2010; Yao et al., 2010). Consistent with expectations, soil mineral $\mathrm{N}$ content was lower in the GCM and GUM since mineral $\mathrm{N}$ was slowly released from organic manure mineralization, as compared to the rapid release of mineral $\mathrm{N}$ with urea application in GUN, and consequently decreasing $\mathrm{N}_{2} \mathrm{O}$ emissions. In addition, the significantly increased $\mathrm{CH}_{4}$ emissions from GCM indicated the apparently prevailing anaerobic conditions in soils. At the same time, the higher soil temperature and DOC contents in GCM would further stimulate soil denitrifier activity and efficiency during the denitrification process, which benefits nitrate finally transformed into $\mathrm{N}_{2}$ rather than the middle product of $\mathrm{N}_{2} \mathrm{O}$ (Millar and Baggs, 2005; Qin et al., 2010). Also, Kramer et al. (2006) conducted lab and field studies and found that soils with organic fertilization exhibited higher potential denitrification rates, greater denitrification efficiency and higher $\mathrm{N}_{2}$ emissions than the soils farmed with synthetic $\mathrm{N}$ fertilizers.

Over the entire rice-fallow system, the direct emission factors of $\mathrm{N}_{2} \mathrm{O}$ were 1.52 and $4.01 \%$ due to urea applications under conventional paddy and GCRPS, respectively, which is obviously higher than the IPCC default value of $0.30 \%$ for rice paddy fields and $1 \%$ for upland croplands (IPCC, 2006). Compared with the reported annual direct emission factors of $0.34-2.50 \%$ for $\mathrm{N}_{2} \mathrm{O}$ in Chinese upland-rice rotation systems (Zheng et al., 2000, 2004; Zou et al., 2005b; Liu et al., 2010; Yao et al., 2010, 2013b), the direct emission factor is comparable for the CUN but relatively high for the GUN. However, $\mathrm{N}_{2} \mathrm{O}$ emissions from GUN were substantially reduced by manure application, giving annual direct emission factors of 0.087 and $0.50 \%$ under GCM and GUM, respectively. This further confirms that the application of organic fertilizers indeed decreases annual direct emission factors of $\mathrm{N}_{2} \mathrm{O}$ as was also reported in previous studies (e.g., Pathak et al., 2002; Yao et al., 2010).

\subsection{Grain yield, NEGE and implications for assessing GCRPS}

In the present study, the grain yields under conventional paddy and GCRPS ranged from 5.49 to $7.92 \mathrm{Mg} \mathrm{ha}^{-1}$ and 6.05 to $7.97 \mathrm{Mg} \mathrm{ha}^{-1}$, respectively, which is within the range of rice grain yields for the conventional paddy (3.63 to 8.77 $\mathrm{Mg} \mathrm{ha}^{-1}$ ) and GCRPS (4.27 to $9.97 \mathrm{Mg} \mathrm{ha}^{-1}$ ) estimated at a large regional scale in central China (Liu et al., 2013). Across the GNN and GUN treatments under GCRPS, the grain yield was estimated to be an average of $6.87 \mathrm{Mg} \mathrm{ha}^{-1}$, which is approximately $3 \%$ higher than that of the conventional paddy. This result is comparable to previous estimates on the stimulating effects of GCRPS on grain yields ( $\mathrm{Qu}$ et al., 2012; Liu et al., 2013).

Although GCRPS reduced the greenhouse effects of $\mathrm{CH}_{4}$ emission by $83 \%$ when practiced together with urea application (i.e., GUN), this reduction was fully compensated by increases (approximately 136\%) in annual emissions of the even more potent GHG $\mathrm{N}_{2} \mathrm{O}$ (Table 5). Similar results have been observed in other studies where increased $\mathrm{N}_{2} \mathrm{O}$ emissions substantially offset the decreases in $\mathrm{CH}_{4}$ emissions resulting from changes in water management $(\mathrm{Xu}$ et al., 2004; Kreye et al., 2007; Hou et al., 2012; Yang et al., 2012). For the GCM and GUM treatments, however, the increased $\mathrm{N}_{2} \mathrm{O}$ emissions did not compensate for the climate benefits from decreased $\mathrm{CH}_{4}$ emissions, resulting in the lower annual aggregate emissions of $\mathrm{CH}_{4}$ and $\mathrm{N}_{2} \mathrm{O}$ compared to the GUN and CUN. In addition, as estimated in this study, GCRPS tended to reduce the $\mathrm{C}$ loss in soils (Table 5). Averaging across GNN and GUN under GCRPS, the annual NEGE was $8.83 \mathrm{MgCO}_{2}$-eq ha ${ }^{-1} \mathrm{yr}^{-1}$, which is $19 \%$ lower compared to the conventional paddy, indicating that water-saving GCRPS management tended to reduce net greenhouse effects from rice-based cropping systems. Within the GCRPS, GUM and GCM further decreased the annual NEGE compared to the GNN and GUN. Based on the results of grain yield and NEGE, therefore, water-saving GCRPS management, particularly when practiced together 
with organicfertilizeramendments, is beneficial for increasing grain yields while simultaneously reducing total GHG emissions during crop production.

\section{Conclusions}

The introduction of water-saving GCRPS technology has a high potential to increase rice grain yields and to significantly reduce irrigation water demand for rice cultivation. However, it remains unknown if this new rice production technique will in the end not lead to pollution swapping of GHG emissions, i.e., from $\mathrm{CH}_{4}$ emissions for conventional paddy fields to increased soil $\mathrm{N}_{2} \mathrm{O}$ and $\mathrm{CO}_{2}$ emissions for ground cover rice production systems. This study provides for the first time an assessment of the net effect of GCRPS on the annual GHG balance. Averaging across all the fertilizer treatments, GCRPS greatly increased annual $\mathrm{N}_{2} \mathrm{O}$ emissions and significantly decreased annual $\mathrm{CH}_{4}$ emissions, while GCRPS had no effect on annual soil $\mathrm{CO}_{2}$ emissions compared to the conventional paddy. By integrating $\mathrm{CH}_{4}$ and $\mathrm{N}_{2} \mathrm{O}$ emissions and soil carbon sequestration capacities, the estimated annual net greenhouse gas exchanges in all the GCRPS treatments tended to be lower as compared to the conventional paddy, highlighting the potential feasibility of GCRPS in reducing net greenhouse effects. Overall, from the environmental sustainability point of view for the hilly rice-based cropping system, the implementation of water-saving GCRPS technology, particularly practiced together with organic fertilizer supplement, seems to be a very promising approach to increase grain yields, reduce aggregate emissions of $\mathrm{CH}_{4}$ and $\mathrm{N}_{2} \mathrm{O}$ and to stimulate soil carbon sequestration.

\section{The Supplement related to this article is available online at doi:10.5194/bg-11-6221-2014-supplement.}

Acknowledgements. This project was funded by the Ministry of Science and Technology of China (2012CB417106), the National Nature Science Foundation of China (51139006, 41075109, 41305129, 41321064). We wish to thank the Shiyan Municipal Bureau of Agriculture for routine maintenance during the field trial. We are also grateful to Haibo Dong, Rui Wang and Yongfeng Fu for their assistance in field and laboratory measurements.

Edited by: Y. Kuzyakov

\section{References}

Adviento-Borbe, M. A. A., Haddix, M. L., Binder, D. L., Walters, D. T., and Dobermann, A.: Soil greenhouse gas fluxes and global warming potential in four high-yielding maize systems, Glob. Change Biol., 13, 1972-1988, 2007.
Akiyama, H., Yagi, K., and Yan, X. Y.: Direct $\mathrm{N}_{2} \mathrm{O}$ emissions from rice paddy fields: summary of available data, Global Biogeochem. Cy., 19, GB1005, doi:10.1029/2004GB002378, 2005.

Banger, K., Tian, H., and Lu, C.: Do nitrogen fertilizers stimulate or inhibit methane emissions from rice fields? Glob. Change Biol., 18, 3259-3267, 2012.

Belder, P., Bouman, B. A. M., Cabangon, R., Guoan, L., Quilang, E. J. P., Li, Y. H., Spiertz, J. H. J., and Tuong, T. P.: Effect of watersaving irrigation on rice yield and water use in typical lowland conditions in Asia, Agric. Water Manage., 65, 193-210, 2004.

Bhattacharyya, P., Roy, K., Neogi, S., Chakravorti, S., Behera, K., Das, K., Bardhan, S., and Rao, K.: Effect of long-term application of organic amendment on $\mathrm{C}$ storage in relation to global warming potential and biological activities in tropical flooded soil planted to rice, Nutr. Cycl. Agroecosyst., 94, 273-285, 2012.

Bodelier, P. L. E. and Laanbroek, H. J.: Nitrogen as a regulatory factor of methane oxidation in soils and sediments, FEMS Microbiol. Ecol., 47, 265-277, 2004.

Bond-Lamberty, B. and Thomson, A.: A global database of soil respiration data, Biogeosciences, 7, 1915-1926, doi:10.5194/bg-71915-2010, 2010.

Bouman, B. A. M.: A conceptual framework for the improvement of crop water productivity at different spatial scales, Agric. Syst., 93, 43-60, 2007.

Bouman, B. A. M. and Tuong, T. P.: Field water management to save water and increase its productivity in irrigated lowland rice, Agric. Water Manage., 49, 11-30, 2001.

Bouman, B. A. M., Hengsdijk, H., Hardy, B., Bindraban, P. S., Tuong, T. P., and Ladha, J. K. (Eds.): Water-wise rice production, Proceedings of the International Workshop on Water-wise Rice Production 8-11 April 2002, pp. 356, Los Baños, Philippines, International Rice Research Institute, 2002.

Bouman, B. A. M., Humphreys, E., Tuong, T. P., and Barker, R.: Rice and water, Adv. Agron., 92, 187-237, 2006.

Cai, Z., Yan, X., Yan, G., Xu, H., Tsuruta, H., Yagi, K., and Minami, K.: Methane and nitrous oxide emissions from rice paddy fields as affected by nitrogen fertilisers and water management, Plant Soil, 196, 7-14, 1997.

Cai, Z., Shan, Y., and Xu, H.: Effects of nitrogen fertilization on $\mathrm{CH}_{4}$ emissions from rice fields, Soil Sci. Plant Nutr., 53, 353-361, 2007.

Castro, M. S., Steudler, P. A., Melillo, J. M., Aber, J. D., and Bowden, R. D.: Factors controlling atmospheric methane consumption by temperate forest soils, Global Biogeochem. Cy., 9, 1-10, 1995.

Dittert, K., Lin, S., Kreye, C., Zheng, X., Xu, Y., Lu, X., Shen, Q., Fan, X., and Sattelmacher, B.: Saving water with Ground Cover Rice Production Systems (GCRPS) at the price of increased greenhouse gas emissions?, in: Water-Wise Rice Production, edited by: Bouman, B. A. M., Hengsdijk, H., Hardy, B., Bindraban, P. S., Tuong, T. P., and Ladha, J. K., 197-206, International Rice Research Institute, Los Baños, Philippines, 2002.

Dobbie, K. E., McTaggart, I. P., and Smith, K. A.: Nitrous oxide emissions from intensive agricultural systems: variations between crops and seasons, key driving variables, and mean emission factors, J. Geophys. Res., 104, 26891-26899, 1999.

Dong, H., Yao, Z., Zheng, X., Mei, B., Xie, B., Wang, R., Deng, J., Cui, F., and Zhu J.: Effect of ammonium-based, non-sulfate fertilizers on $\mathrm{CH}_{4}$ emissions from a paddy field with a typi- 
cal Chinese water management regime, Atmos. Environ., 45, 1095-1101, 2011.

FAO (Food and Agriculture Organization): FAOSTAT online electronic data base, http://faostat.fao.org/, 2011.

Fog, K.: The effect of added nitrogen on the rate of decomposition of organic matter, Biol. Rev. Camb. Philos. Soc., 63, 433-462, 1988.

Gentile, R., Vanlauwe, B., Chivenge, P., and Six, J.: Interactive effects from combining fertilizer and organic residue inputs on nitrogen transformations, Soil Biol. Biochem., 40, 2375-2384, 2008.

Hou, H., Peng, S., Xu, J., Yang, S., and Mao, Z.: Seasonal variations of $\mathrm{CH}_{4}$ and $\mathrm{N}_{2} \mathrm{O}$ emissions in response to water management of paddy fields located in Southeast China, Chemosphere, 89, 884-892, 2012.

$\mathrm{Hu}, \mathrm{R}$., Hatano, R., Kusa, K., and Sawamoto, T.: Soil respiration and net ecosystem production in an onion field in central Hokkaido, Japan, Soil Sci. Plant Nutr., 50, 27-33, 2004.

Hu, X., Su, F., Ju, X., Gao, B., Oenema, O., Christie, P., Huang, B., Jiang, R., and Zhang, F.: Greenhouse gas emissions from a wheat-maize double cropping system with different nitrogen fertilization regimes, Environ. Pollut., 176, 198-207, 2013.

Hutchinson, G. L. and Mosier, A. R.: Improved soil cover method for field measurement of nitrous oxide fluxes, Soil Sci. Soc. Am. J., 45, 311-316, 1981.

IPCC (Intergovernmental Panel on Climate Change), IPCC Guidelines for National Greenhouse Gas Inventories [M], 4, Agriculture, Forestry and Other Land Use, IPCC / IGES, Hayama, Japan, 2006

IPCC (Intergovernmental Panel on Climate Change), Climate Change 2007: The Physical Science Basis, Contribution of Working Group I to the Fourth Assessment Report of the Intergovernmental Panel on Climate Change, edited by: Solomon, S., Qin, D., Manning, M., Chen, Z., Marquis, M., Averyt, K. B., Tignor, M., and Miller, H. L., 498-540, Cambridge University Press, Cambridge, United Kingdom and New York, NY, USA, 2007.

Iqbal, J., Hu, R., Lin, S., Hatano, R., Feng, M., Lu, L., Ahamadou, B., and Du, L.: $\mathrm{CO}_{2}$ emission in a subtropical red paddy soil (Ultisol) as affected by straw and $\mathrm{N}$-fertilizer applications: A case study in Southern China, Agr. Ecosyst. Environ., 131, 292-302, 2009

Kramer, S. B., Reganold, J. P., Glover, J. D., Bohannan, B. J. M., and Mooney, H. A.: Reduced nitrate leaching and enhanced denitrifier activity and efficiency in organically fertilized soils, PNAS, 103, 4522-4527, 2006.

Kreye, C., Dittert, K., Zheng, X., Zhang, X., Lin, S., Tao, H., and Sattelmacher, B.: Fluxes of methane and nitrous oxide in watersaving rice production in north China, Nutr. Cycl. Agroecosyst., 77, 293-304, 2007.

Lee, D. K., Doolittle, J. J., and Owens, V. N.: Soil carbon dioxide fluxes in established switchgrass land managed for biomass production, Soil Biol. Biochem., 39, 178-186, 2007.

Linquist, B., Van Groenigen, K., Adviento-Borbe, M., Pittelkow, C., and Van Kessel, C.: An agronomic assessment of greenhouse gas emissions from major cereal crops, Glob. Change Biol., 18, 194-209, 2012.

Liu, L. and Greaver, T. L.: A review of nitrogen enrichment effects on three biogenic GHGs: the $\mathrm{CO}_{2}$ sink may be largely offset by stimulated $\mathrm{N}_{2} \mathrm{O}$ and $\mathrm{CH}_{4}$ emission, Ecol. Lett., 12, 1103-1117, 2009.

Liu, M., Lin, S., Dannenmann, M., Tao, Y., Saiz, G., Zuo, Q., Sippel, S., Wei, J., Cao, J., Cai, X., and Butterbach-Bahl, K.: Do water-saving ground cover rice production systems increase grain yields at regional scales?, Field Crop. Res., 150, 19-28, 2013.

Liu, S., Qin, Y., Zou, J., and Liu, Q.: Effects of water regime during rice-growing season on annual direct $\mathrm{N}_{2} \mathrm{O}$ emission in a paddy rice-winter wheat rotation system in southeast China, Sci. Total Environ., 408, 906-913, 2010.

Maestre, F. T. and Cortina, J.: Small-scale spatial variation in soil $\mathrm{CO}_{2}$ efflux in a Mediterranean semiarid steppe, Appl. Soil Ecol., 23, 199-209, 2003.

Millar, N. and Baggs, E. M.: Relationships between $\mathrm{N}_{2} \mathrm{O}$ emissions and water-soluble $\mathrm{C}$ and $\mathrm{N}$ contents of agroforestry residues after their addition to soil, Soil Biol. Biochem., 37, 605-608, 2005.

Minamikawa, K. and Sakai, N.: The effect of water management based on soil redox potential on methane emission from two kinds of paddy soil in Japan, Agr. Ecosyst. Environ., 107, 397-407, 2005.

Nishimura, S., Sawamoto, T., Akiyama, H., Sudo, S., and Yagi, K.: Methane and nitrous oxide from a paddy field with Japanese conventional water management and fertilizer application, Global Biogeochem. Cy., 18, GB2017, doi:10.1029/2003GB002207, 2004.

Pathak, H., Bhatia, A., Prasad, S., Singh, S., Kumar, S., Jain, M. C., and Kumar, U.: Emissions of nitrous oxide from rice-wheat systems of Indo-Gangetic plains of India, Environ. Monit. Assess., 77, 163-178, 2002.

Qin, Y., Liu, S., Guo, Y., Liu, Q., and Zou, J.: Methane and nitrous oxide emissions from organic and conventional rice cropping systems in Southeast China, Biol. Fertil. Soils, 46, 825-834, 2010.

Qu, H., Tao, H., Tao, Y., Liu, M., Shen, K., and Lin, S.: Ground cover rice production system increases yield and nitrogen recovery efficiency, Agron. J., 104, 1399-1407, 2012.

Raich, J. W. and Tufekcioglu, A.: Vegetation and soil respiration: Correlations and controls, Biogeochemistry, 48, 71-90, 2000.

Rochette, P. and Gregorich, E. G.: Dynamics of soil microbial biomass $\mathrm{C}$, soluble organic $\mathrm{C}$ and $\mathrm{CO}_{2}$ evolution after three years of manure application, Can. J. Soil Sci., 78, 283-290, 1998.

Sass, R. L., Fisher, F. M., Ding, A., and Huang, Y.: Exchange of methane from rice fields: national, regional, and global budgets, J. Geophys. Res., 104, 26943-26951, 1999.

Schindlbacher, A., Zechmeister-Boltenstern, S., and ButterbachBahl, K.: Effects of soil moisture and temperature on $\mathrm{NO}, \mathrm{NO}_{2}$ and $\mathrm{N}_{2} \mathrm{O}$ emissions from European forest soils, J. Geophys. Res., 109, D1702, doi:10.1029/2004JD004590, 2004.

Shang, Q., Yang, X., Gao, C., Wu, P., Liu, J., Xu, Y., Shen, Q., Zou, J., and Guo, S.: Net annual global warming potential and greenhouse gas intensity in Chinese double rice-cropping systems: a 3year field measurement in long-term fertilizer experiments, Glob Change Biol., 17, 2196-2210, 2011.

Smith, K. A., Ball, T., Conen, F., Dobbie, K. E., Massheder, J., and Rey, A.: Exchange of greenhouse gases between soil and atmosphere: interactions of soil physical factors and biological processes, Eur. J. Soil Sci., 54, 779-791, 2003. 
Smith, P., Martino, D., Cai, Z., Gwary, D., Janzen, H., Kumar, P., McCarl, B., Ogle, S., O'Mara, F., Rice, C., Scholes, B., and Sirotenko, O.: Agriculture, in: Climate Change 2007: Mitigation, Contribution of work group III to the fourth assessment report of the Intergovernmental Panel on Climate Change, edited by: Metz, B., Davidson, O. R., Bosch, P. R., Dave, R., and Meyer, L. A., 497-540, Cambridge University Press, Cambridge, UK and New York, NY, USA, 2007.

Wang, J., Rothausen, S., Conway, D., Zhang, L., Xiong, W., Holman, I., and Li, Y.: China's water-energy nexus: greenhouse-gas emissions from groundwater use for agriculture, Environ. Res. Lett., 7, 014035, doi:10.1088/1748-9326/7/1/014035, 2012.

Wang, K., Zheng, X., Pihlatie, M., Vesala, T., Liu, C., Haapanala, S., Mammarella, I., Rannik, Ü., and Liu, H.,: Comparison between static chamber and tunable diode laser-based eddy covariance techniques for measuring nitrous oxide fluxes from a cotton field, Agr. Forest Meteorol., 171-172, 9-19, 2013.

Wang, W., Dalal, R., Reeves, S., Butterbach-Bahl, K., and Kiese, R.: Greenhouse gas fluxes from an Australian subtropical cropland under long-term contrasting management regimes, Glob. Change Biol., 17, 3089-3101, 2011.

Wang, Y. H., Wang, Y. S., and Ling, H.: A new carrier gas type for accurate measurement of $\mathrm{N}_{2} \mathrm{O}$ by GC-ECD, Adv. Atmos. Sci., 27, 1322-1330, 2010.

Williams, E. J., Hutchinson, G. L., and Fehsenfeld, F. C.: $\mathrm{NO}_{\mathrm{x}}$ and $\mathrm{N}_{2} \mathrm{O}$ emissions from soil, Global Biogeochem. Cy., 6, 351-388, 1992.

Xie, B., Zheng, X., Zhou, Z., Zhu, B., Chen, X., Shi, Y., Wang, Y., Zhao, Z., Liu, C., Yao, Z., and Zhu J.: Effects of nitrogen fertilizer on $\mathrm{CH}_{4}$ emission from rice fields: multi-site field observations, Plant Soil, 326, 393-401, 2010.

Xu, Y., Shen, Q., Li, M., Dittert, K., and Sattelmacher, B.: Effect of soil water status and mulching on $\mathrm{N}_{2} \mathrm{O}$ and $\mathrm{CH}_{4}$ emission from lowland rice field in China, Biol. Fertil. Soils, 39, 215-217, 2004.

Yagi, K., Tsuruta, H., Kanda, K., and Minami, K.: Effect of water management on methane emission from a Japanese rice paddy field: automated methane monitoring, Global Biogeochem. Cy., 10, 255-267, 1996.

Yan, X., Cai, Z., Ohara, T., and Akimoto, H.: Methane emission from rice fields in mainland China: Amount and seasonal and spatial distribution, J. Geophys. Res., 108, 4505, doi:10.1029/2002JD003182, 2003.

Yan, X., Akiyama, H., Yagi, K., and Akimoto, H.: Global estimations of the inventory and mitigation potential of methane emissions from rice cultivation conducted using the 2006 Intergovernmental Panel on Climate Change Guidelines, Global Biogeochem. Cy., 23, GB2002, doi:10.1029/2008GB003299, 2009.

Yang, S., Peng, S., Xu, J., Luo, Y., and Li, D.: Methane and nitrous oxide emissions from paddy field as affected by water-saving irrigation, Phy. Chem. Earth, 53-54, 30-37, 2012.
Yao, Z., Zheng, X., Xie, B., Liu, C., Mei, B., Dong, H., ButterbachBahl, K., and Zhu, J.: Comparison of manual and automated chambers for field measurements of $\mathrm{N}_{2} \mathrm{O}, \mathrm{CH}_{4}, \mathrm{CO}_{2}$ fluxes from cultivated land, Atmos. Environ., 43, 1888-1896, 2009.

Yao, Z., Zhou, Z., Zheng, X., Xie, B., Mei, B., Wang, R., Butterbach-Bahl, K., and Zhu, J.: Effects of organic matter incorporation on nitrous oxide emissions from rice-wheat rotation ecosystems in China, Plant Soil, 327, 315-330, 2010.

Yao, Z., Zheng, X., Dong, H., Wang, R., Mei, B., and Zhu, J.: A 3year record of $\mathrm{N}_{2} \mathrm{O}$ and $\mathrm{CH}_{4}$ emissions from a sandy loam paddy during rice seasons as affected by different nitrogen application rates, Agr. Ecosyst. Environ., 152, 1-9, 2012.

Yao, Z., Zheng, X., Wang, R., Xie, B., Butterbach-Bahl, K., and Zhu, J.: Nitrous oxide and methane fluxes from a rice-wheat crop rotation under wheat residue incorporation and no-tillage practices, Atmos. Environ., 79, 641-649, 2013a.

Yao, Z., Zheng, X., Wang, R., Dong, H., Xie, B., Mei, B., Zhou, Z., and Zhu, J.: Greenhouse gas fluxes and NO release from a Chinese subtropical rice-winter wheat rotation system under nitrogen fertilizer management, J. Geophys. Res.-Biogeo., 118, 623-638, 2013b.

Zheng, X., Wang, M., Wang, Y., Shen, R., Gou, J., Li, J., Jin, J., and $\mathrm{Li}, \mathrm{L}$. T.: Impacts of soil moisture on nitrous oxide emission from croplands: a case study on the rice-based agro-ecosystem in Southeast China, Chemosphere-Global Change Sci., 2, 207-224, 2000.

Zheng, X., Han, S., Huang, Y., Wang, Y., and Wang, M.: Re-quantifying the emission factors based on field measurements and estimating the direct $\mathrm{N}_{2} \mathrm{O}$ emission from Chinese croplands, Global Biogeochem. Cy., 18, GB2018, doi:10.1029/2003GB002167, 2004.

Zheng, X., Mei, B., Wang, Y. H., Xie, B., Wang, Y. S., Dong, H., Xu, H., Chen, G., Cai, Z., Yue, J., Gu, J., Su, F., Zou, J., and Zhu, J.: Quantification of $\mathrm{N}_{2} \mathrm{O}$ fluxes from soil-plant systems may be biased by the applied gas chromatograph methodology, Plant Soil, 311, 211-234, 2008.

Zhou, S. D., Herzfeld, T., Glauben, T., Zhang, Y. H., and Hu, B. C.: Factors affecting Chinese farmers' decisions to adopt a watersaving technology, Can. J. Agric. Econ., 56, 51-61, 2008.

Zou, J., Huang, Y., Jiang, J., Zheng, X., and Sass, R. L.: A 3-year field measurement of methane and nitrous oxide emissions from rice paddies in China: Effects of water regime, crop residue, and fertilizer application, Global Biogeochem. Cy., 19, GB2021, doi:10.1029/2004GB002401, 2005a.

Zou, J., Huang, Y., Lu, Y., Zheng, X., and Wang, Y.: Direct emission factor for $\mathrm{N}_{2} \mathrm{O}$ from rice-winter wheat rotation systems in southeast China, Atmos. Environ., 39, 4755-4765, 2005 b. 